NBER WORKING PAPER SERIES

\title{
IN SEARCH OF REFORMS FOR GROWTH: NEW STYLIZED FACTS ON POLICY AND GROWTH OUTCOMES
}

\author{
William Easterly \\ Working Paper 26318 \\ http://www.nber.org/papers/w26318 \\ NATIONAL BUREAU OF ECONOMIC RESEARCH \\ 1050 Massachusetts Avenue \\ Cambridge, MA 02138 \\ September 2019
}

I am grateful for comments received at presentations of preliminary results at the NYU Development Faculty Meeting, at the World Bank (including the discussant Aart Kraay), and of this paper at the UC Berkeley Goldman School Seminar, the Graduate Center of CUNY, at the UC Berkeley Haas School Political Economy and Governance Conference, at the World Bank Globalization Conference in Kuala Lumpur, as well as from Hunt Alcott, Anne Case, Michael Clemens, Douglas Irwin, Ross Levine, Dani Rodrik, Martin Rotemberg, Laura Trucco, and Dennis Whittle. I gratefully acknowledge research assistance from Juan Jose Matta. The views expressed herein are those of the author and do not necessarily reflect the views of the National Bureau of Economic Research.

NBER working papers are circulated for discussion and comment purposes. They have not been peer-reviewed or been subject to the review by the NBER Board of Directors that accompanies official NBER publications.

(C) 2019 by William Easterly. All rights reserved. Short sections of text, not to exceed two paragraphs, may be quoted without explicit permission provided that full credit, including () notice, is given to the source. 
In Search of Reforms for Growth: New Stylized Facts on Policy and Growth Outcomes

William Easterly

NBER Working Paper No. 26318

September 2019

JEL No. O1,O4,O47

\begin{abstract}
$\underline{\text { ABSTRACT }}$
The lack of growth response to "Washington Consensus" policy reforms in the 1980s and 1990s led to widespread doubts about the value of such reforms. This paper updates these stylized facts by analyzing moderate to extreme levels of inflation, black market premiums, currency overvaluation, negative real interest rates and abnormally low trade shares to GDP. It finds three new stylized facts: (1) policy outcomes worldwide have improved a lot since the 1990s, (2) improvements in policy outcomes and improvements in growth across countries are correlated with each other (3) growth has been good after reform in Africa and Latin America, in contrast to the "lost decades" of the 80s and 90s. This paper makes no claims about causality. However, if the old stylized facts on disappointing growth accompanying reforms led to doubts about economic reforms, new stylized facts should lead to some positive updating of such beliefs.
\end{abstract}

William Easterly

New York University

Department of Economics

19 W. 4th Street, 6th floor

New York NY 10012

and NBER

william.easterly@nyu.edu 


\section{Introduction}

Many authors (including this one) have proclaimed the failure of a package of market-oriented reforms proposed in the 1980s and 1990s -- variously known as the Washington Consensus, IMF/World Bank structural adjustment, globalization, or neoliberalism. ${ }^{2}$ This paper seeks to update the stylized facts on policies and growth that influenced this verdict. While not claiming any causal interpretation on policy reforms and growth, this paper argues that theories of policies and growth should at least seek to keep updating and explaining such stylized facts.

The earlier stylized facts featured the zero or low per capita growth in the regions that were the focus of reform: Africa and Latin America. This produced some strong conclusions on the Washington Consensus (in both the academic literature and the applied policy debates): "Proponents and critics alike agree that the policies spawned by the Washington Consensus have not produced the desired results...it is fair to say that nobody really believes in the Washington Consensus anymore. The debate now is not over whether the Washington Consensus is dead or alive, but over what will replace it” (Rodrik 2006).

This author also had doubts: "Repeated \{structural\} adjustment lending ...fails to show any positive effect on policies or growth (Easterly 2005a).” Easterly 2001 noted "The Lost Decades" for Latin America and Africa, a discouraging outcome of "Stagnation in Spite of Policy Reform 1980-1998”. Rodrik (2006) could declare that even the "most ardent supporters of reform now concede that growth has been below expectations in Latin America" and "success stories in Sub-Saharan Africa few and far in between.” The World Bank (2005) noted that "Some countries managed to sustain rapid growth with just modest reforms, and others could not grow even after implementing a wide range of reforms."

The doubts about the Washington Consensus had begun even earlier. Rodrik (1997) had asked "Has globalization gone too far?” Krugman (1995) noted "the real economic performance of countries that had recently adopted Washington consensus policies...was distinctly disappointing." Sebastian Edwards, the World Bank's Vice President and Chief Economist for Latin America noted in 1995 that

\footnotetext{
${ }^{2}$ The same debates also appear of course in both history and the present in rich countries. See Irwin (2017) on US history.
} 
"after all the reforms, the efforts, and the accolades from the financial media, the region as a whole is making little progress towards breaking out of the quagmire of poverty" (Burki and Edwards, 1995). Edwards also said in a separate publication about Latin America, "the results in terms of growth and social progress have not yet met expectations" (Edwards, 1995). Since John Williamson had defined the Washington Consensus in $1990,{ }^{3}$ many economists doubted it almost as soon as the first post-reform numbers appeared.

More recently, Naidu, Rodrik, and Zucman (2019) have called for a new "Economics after Neoliberalism" because "many of the dominant policy ideas of the last few decades are supported neither by sound economics nor by good evidence."

The literature on policies and growth has some well-known shortcomings. It failed to resolve causality from macro policies to growth, or even to measure macro policy effort directly as opposed to indirect and endogenous measures of policy outcomes. If it were possible to resolve these problems, the literature would have probably done so by now.

Yet the quotes above show that the stylized facts on policy outcomes and growth that poor growth outcomes accompanied improved policy outcomes -- influenced beliefs on the policy-growth relationship. If so, it seems strange that these stylized facts have not been updated in the literature, as much more data have become available with the passage of time. Increased emphasis on resolving causality is welcome, but it should not prevent updating of influential non-causal stylized facts. It is the purpose of this paper to fill this gap in the literature.

This paper will report new stylized facts. First, there has been additional and quite remarkable progress on reform outcomes since the late 1990s -- this is a principal finding of this paper. Earlier judgments on the reforms often happened before the reform process was complete and/or had enough post-reform growth data to evaluate reforms. This first stylized fact could also be consistent with an exogenous international trend towards reform, although of course again causality cannot be proven.

\footnotetext{
${ }^{3}$ Williamson (1990)
} 
The second stylized fact is that there is a strong correlation between improvements in policy outcomes and changes in growth outcomes.

The third stylized fact is that growth has recovered in Africa and Latin America in the new millennium, and the regression of growth on policy outcomes explains a substantial part of the growth recovery.

There is no obvious way to resolve causality in the correlation in the second stylized fact between growth and policy outcomes. The correlation could reflect some combination of theoretical stories: (1) the correlation could be spuriously driven by some third factor, or (2) it could reflect reverse causality from growth to policy, or (3) it could reflect causality from policy to growth.

Hypothesis (1) can be at least partially tested by assessing whether some observable third factors account for any correlations between policy outcomes and growth. Hypothesis (2) should lead to theorizing on how bad growth outcomes could cause bad policy outcomes, which seems plausible but has been little developed in the literature so far. Hypothesis (3) - that reforms would increase growth -- has been the prediction of many endogenous growth models. The failure of this prediction was the basis of the earlier literature's disappointment with the growth that accompanied reforms. If reform outcomes now successfully predict growth, the previous disappointment now needs an update.

\section{Previous literature on reforms and growth}

Another common concern in the literature has been about the robustness of previous growth and policy correlations, given fears of publication bias and specification searching (Levine and Renelt 1992, Durlauf, Johnson, Temple 2006). Concerns about robustness were reinforced by the failure of the predicted postreform growth in Africa and Latin America in the 1980s and 1990s.

There had been many previous cross-country regressions suggesting positive growth effects of "good policies" as defined by the Washington Consensus (e.g. Dollar 1992, Sachs and Warner 1995, Harrison 1996, Edwards 1998, Frankel and Romer 1999, Dollar and Kraay 2004). These failed to convince the Washington Consensus doubters -partly because of the robustness concerns and partly because of the actual post-reform stagnation. 
Rodriguez and Rodrik 2001 overturned (using new data or plausible specification changes) the results by Dollar 1992, Sachs and Warner 1995, Edwards 1998, and Frankel and Romer 1999. Rodrik 2000 overturned the results by Dollar and Kraay. ${ }^{4}$ The previous "good policies raise growth" results also failed to explain the aggregate stagnation in Africa and Latin America despite reforms (Easterly 2001).

Some methods used a single date of reform (like Sachs and Warner 1995), which had advantages and disadvantages. They made possible a consideration of nonparametric cumulative effects on income or using difference-in-differences methods. But they may have too many possibilities as to which indicators are included and how much they have to change to define the date of reform, leading to disagreements as to when reform happened. Fischer's 1995 contemporaneous discussion of Sachs and Warner questioned the reform dates as substantially off for those countries he knew well. ${ }^{5}$

Overall, doubts were so severe to lead many to proclaim complete ignorance of what does affect growth: "It is not clear that the best way to get growth is to do growth policy. Perhaps making growth happen is ultimately beyond our control. ...Perhaps we will never learn where it will start or what will make it continue.” (Banerjee 2009) Rodrik 2012 suggested "We Learn Nothing from Regressing Economic Growth on Policies.” This author joined these doubts “ $\{$ we $\}$ keep trying to find ways to raise growth in the short to medium run when the economics profession does not have this knowledge” (Easterly 2009). This paper also reconsiders whether such sweeping claims of ignorance may go too far.

A partial answer to doubts about robustness would be to replicate and update previous findings on policies and growth with new data available since previous studies were concluded. Some previous findings suggested that extreme levels of policy outcomes - such as annual inflation higher than 40 percent -- were robustly

\footnotetext{
${ }^{4}$ Rodrik in 2000 was commenting on the working paper version of their paper eventually published in 2004.

${ }^{5}$ More recent papers have gotten important positive findings on policy and growth from the single reform date approach, such as Wacziarg and Welch (2008) (which replicated the positive growth effects of opening using Sachs and Warner's criteria), Marrazzo and Terzi 2017 and Billmeier and Nannicini 2013 (both using the synthetic control method), and Estevadeordal and Taylor 2013 (focusing on tariffs on intermediate and capital goods). Another downside of the reform date approach is that the method discards information as to how growth reacted to different dimensions of reform as well as shrinking the overall sample by limiting to reforming countries with sufficient data to define reform.
} 
associated with poor growth outcomes (Bruno and Easterly 1996, Easterly 2005b). ${ }^{6}$ These papers failed to find evidence for poor growth performance during episodes of somewhat less extreme policy outcomes - such as inflation between 20 and 40 percent - which itself cast doubt on being too zealous about perfecting reforms. ${ }^{7}$

This paper will extend the method of analyzing extremely bad and moderately bad policy outcomes to other policies, specifically -- in addition to inflation -- the black market premium on foreign exchange, ${ }^{8}$ overvaluation of the domestic currency, negative real interest rates on bank savings deposits, and abnormally low trade shares to GDP. Updating the data on these outcomes is not trivial and constitutes one of the main contributions of this paper.

As already noted, these are measures of policy outcomes. They indirectly reflect but do not directly measure policy levers that governments can manipulate. The paper will control for any obvious non-policy factors that affect policy outcomes. It also seems likely that extremely bad policy outcomes reflect some bad policies rather than only some non-policy factors.

Although the Washington Consensus had been at the center of the policy debate, coverage of it can only be incomplete. It is impossible to get good indicators of some major proposed reforms like privatization of state enterprises or deregulation. Budget deficits were also important and have data, but what level of deficit is extremely or moderately bad is context-specific. It depends for example on the existing level of debt and whether new deficit financing is available at concessional interest rates (such as many foreign aid loans).

Also, the Washington Consensus did not make clear how "good" the policy outcomes had to be to satisfy the recommendations, nor were the critics clear how large a departure from the recommendations they would tolerate or advocate. Critics of the Washington Consensus may still agree that inflation greater than 40 percent is an undesirable outcome. However, the possible dangers of such extreme

\footnotetext{
${ }^{6}$ It is well known that incentives for replicating old results are weak. Since the original author has the strongest incentives for replication, the replication exercise in this paper will over-cite this author's past papers!

${ }^{7}$ The inability to reject zero effect on growth of moderate inflation of course did not equate to proving that moderate inflation indeed has zero effect, a point on which even academic authors sometimes make misstatements. This paper will note this caution about interpreting insignificance on the new results in this paper.

${ }^{8}$ Sachs and Warner 1995 had used a dummy variable for the black market premium greater than 20 percent as one measure tracking reform.
} 
policy outcomes were seldom noted in the obituaries for the Washington Consensus.

\section{Measurement of policy outcome indicators}

All data are from the World Bank World Development Indicators (WDI) except where otherwise noted. The Appendix contains additional details about measurement.

Definitions of ranges of extremely bad and moderately bad policy outcomes are arbitrary. These classifications for inflation follow Bruno and Easterly (1996). For other policies, the extremely bad and moderately bad ranges were roughly defined to match intuition and to have a non-trivial minority of outcomes in these ranges over the entire sample. What is most important is that the ranges were not the object of specification searching to get any particular or statistically significant results, on either trends in reforms or correlations with growth. In the Appendix, the paper will run robustness checks on alternative thresholds for extreme and moderate policies. The paper adjusts for non-policy determinants of the policy outcomes whenever there was an obvious way to do so.

Annual GDP per capita growth is available from 1961 to 2015.

Inflation is the annual percent change in consumer prices, available from 1960 to 2015. Inflation is subject to some very extreme outcomes (like thousands of percent) that would dominate any linear regression of growth on inflation rates (the same will be true of the other policy indicators, see Table 1). This is a major reason why some previous papers have preferred to use dummy variables for extreme outcomes rather than entering policy outcomes continuously in a linear regression. Following Bruno and Easterly 1996, extremely bad inflation is defined as greater than 40 percent, while moderately bad is defined as between 20 and 40 percent. 
Table 1: Descriptive Statistics for All Variables

\begin{tabular}{|l|r|r|r|r|r|r|}
\hline & Observations & Mean & Max Dev & Min & Max \\
\hline Per Capita Growth & 8591 & 0.019 & 0.063 & -1.050 & 0.022 \\
\hline Inflation & 7280 & 34 & 484 & -36 & 24411 \\
\hline Dummy for Inflation Over 40 & 7280 & 0.055 & 0.229 & 0 & 1 \\
\hline Dummy for Inflation 20 to 40 & 7280 & 0.073 & 0.260 & 0 & 1 \\
\hline Black Market Premium & 6003 & 16268 & 1168119 & -89 & 90485120 \\
\hline Dummy for BMP Over 40 & 6003 & 0.162 & 0.369 & 0 & 1 \\
\hline Dummy for BMP 20 to 40 & 6003 & 0.067 & 0.250 & 0 & 0 \\
\hline Real Interest Rate & 4990 & 0 & 19 & -99 & 943 \\
\hline Dummy for RIR Below -20 & 4990 & 0.033 & 0.178 & 0 & 1 \\
\hline Dummy for RIR -20 to -5 & 4990 & 0.123 & 0.329 & 0 & 1 \\
\hline Overvaluation & 5611 & 25 & 88 & -97 & 2789 \\
\hline Dummy for Overvaluation Over 100 percent & 5611 & 0.069 & 0.253 & 0 & 1 \\
\hline Dummy for Overvaluation 50 to 100 percent & 5611 & 0.138 & 0.345 & 0 & 1 \\
\hline Residual Trade Share Minus Predicted Share & 7983 & 0 & 46 & -91 & 1 \\
\hline Residual Trade Share Below -40 & 7983 & 0.115 & 0.319 & 0 & 0 \\
\hline Residual Trade Share -40 to -30 & 7983 & 0.096 & 0.295 & 0 & 1 \\
\hline Dummy for Any Civil War & 5089 & 0.194 & 0.395 & 0 & 1 \\
\hline Export Commodity Price Shock & 5054 & 0.008 & 1.022 & -6.685 & 9.677 \\
\hline All Policy Outcome Indicators in Percent & & & -0.024 \\
\hline
\end{tabular}

The black market premium is defined as the percentage excess of the black market domestic currency for US\$ exchange rate over the official exchange rate. Extremely bad black market premiums are defined as above 40 percent, while moderately bad are defined as above 20 percent. $^{9}$

The real interest rate is defined as $(1+$ deposit interest rate)/(1+ inflation rate) -1 . Extremely bad policy outcomes are defined as real interest rates less than -20 percent, while moderately bad is defined as between -5 and -20 percent. ${ }^{10}$

Constructing real overvaluation requires more elaborate steps, including adjustment for non-policy determinants of overvaluation. The method here is similar to Dollar $1992^{11}$. A benchmark overvaluation is first calculated using PPP data, then the overvaluation is corrected for the relative cheapness of nontraded

\footnotetext{
${ }^{9}$ Sachs and Warner 1995 used a black market premium above 20 percent as one of their component measures of a closed economy. Wacziarg and Welch 2008 replicated and updated through 2000 their methodology and also found positive effects of opening on growth.

${ }^{10}$ A negative real interest rate is a tax on savings and represses financial development, as pointed out long ago by McKinnon 1973. A large previous literature presents theory and evidence that financial development raises growth (King and Levine 1993, Levine 1997, Rajan and Zingales 1998, Beck, Levine and Loayza 2000, Levine 2005, Laeven, Levine, and Michalopoulos 2015)

${ }^{11}$ Used since in Easterly and Levine 2003.
} 
goods in poor countries. The range for extremely bad overvaluation is greater than 100 percent, while moderately bad overvaluation is defined as 50 to 100 percent.

The policy outcome variable that is most distantly related to actual policy (and much criticized on these grounds) is the Trade to GDP ratio. However, it featured importantly in the previous literature (e.g. Harrison 1996, Edwards 1998, Frankel and Romer 1999, Dollar and Kraay 2004). Since Rodrik and Rodriguez 2001 and Rodrik 2000 overturned many results on the trade ratio, it seems worth updating the relationship with growth with new data. Other policies above like overvaluation and black market premiums affect the size of trade in the economy, but it is also affected by less easily measured policy variables like tariffs, quotas, and tolerance for corruption at the border. ${ }^{12}$

The Trade to GDP ratio is corrected for population size, since small countries tend to trade more - part of what Frankel and Romer 1999 called "natural openness." Extreme outcomes after making this correction seem likely to reflect some policies repressing trade. An extremely bad trade ratio is defined as more than 40 percentage points less than the predicted trade ratio based on log population size. A moderately bad trade ratio is defined as between 30 and 40 percentage points below the predicted value.

The final dataset is an annual, cross-country panel for each variable, which will first be analyzed for time trends and then will be used for panel regressions of annual growth on annual policy outcomes.

\section{Trends in policy outcome indicators}

This section addresses the first major question in this paper: how much reform had happened at the time there were widespread doubts about the payoff to reform? For each of the policies measured, therefore, this section will show what share of the world's countries were in the moderately bad and extremely bad policy outcome ranges over time.

\footnotetext{
${ }^{12}$ Some previous papers used data on tariffs and non-tariff barriers, but these are typically available for a reduced sample and are a poor measure for the effective rate of protection.
} 


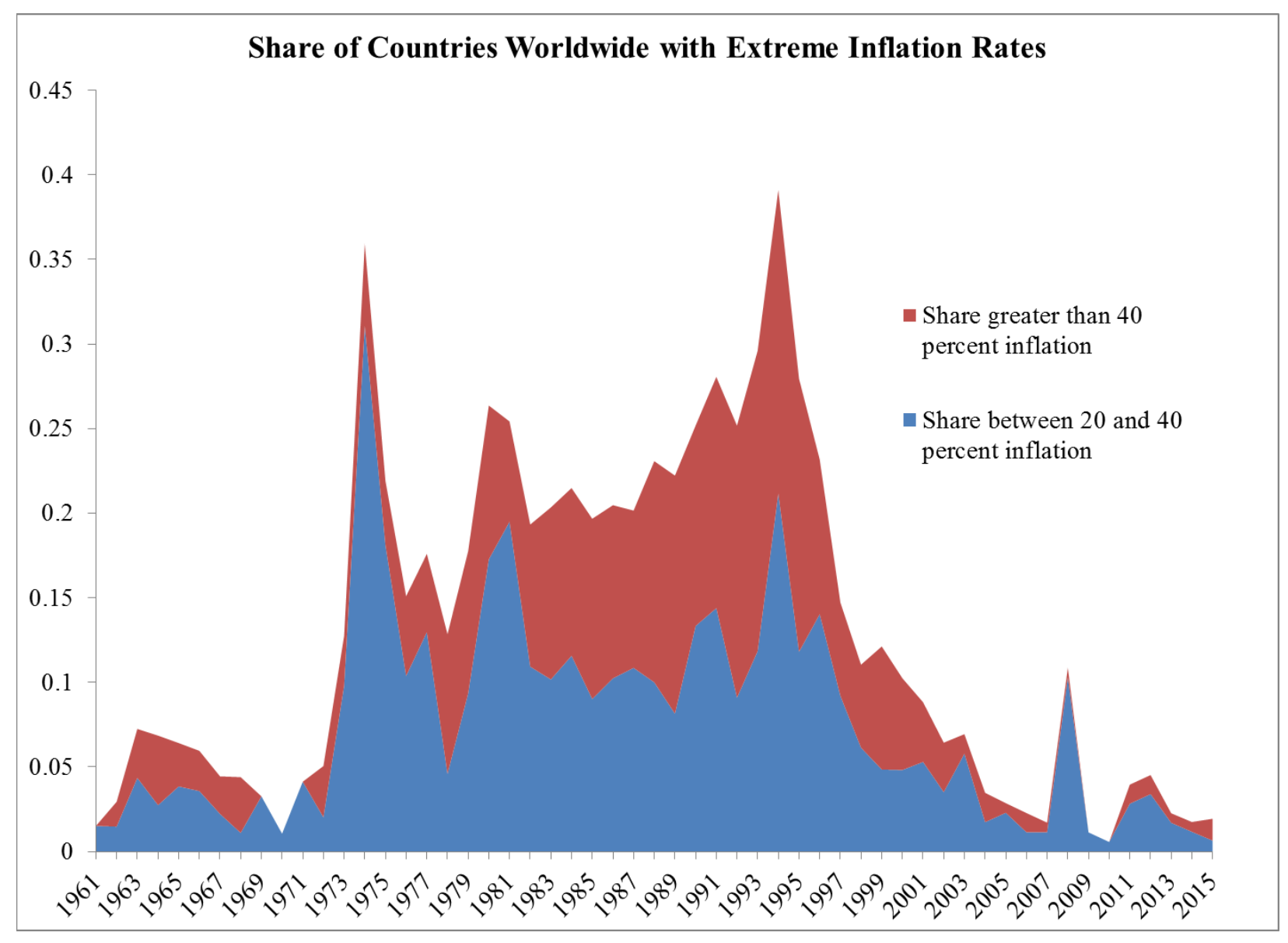

Figure 1a: Share of countries within each range of inflation outcomes

Figure 1a shows inflation outcomes. There is an upward trend towards moderately and extremely bad outcomes in the first half of the sample. The prevalence of moderately and extremely bad inflation in the 1980s (occurring in between 20 and 25 percent of countries) may have been part of the reason why there was advocacy for economic reforms that culminated in the Washington Consensus around 1990. Inflation did not decline immediately after 1990, actually peaking at around 40 percent of countries having moderately or extremely bad outcomes in 1995.

After 1995, there was a strong downward trend in prevalence of bad inflation outcomes into the new millennium, down to about 5 percent of countries in the most recent years. This remarkable turnaround is one of the main results of this paper. 
To the extent that this reflected policy changes, there were indeed reforms. The timing of such reforms did not match exactly either the Washington Consensus advocacy or the onset of doubts. With inflation, not much reform had happened at the time that doubts began about disappointing growth response.

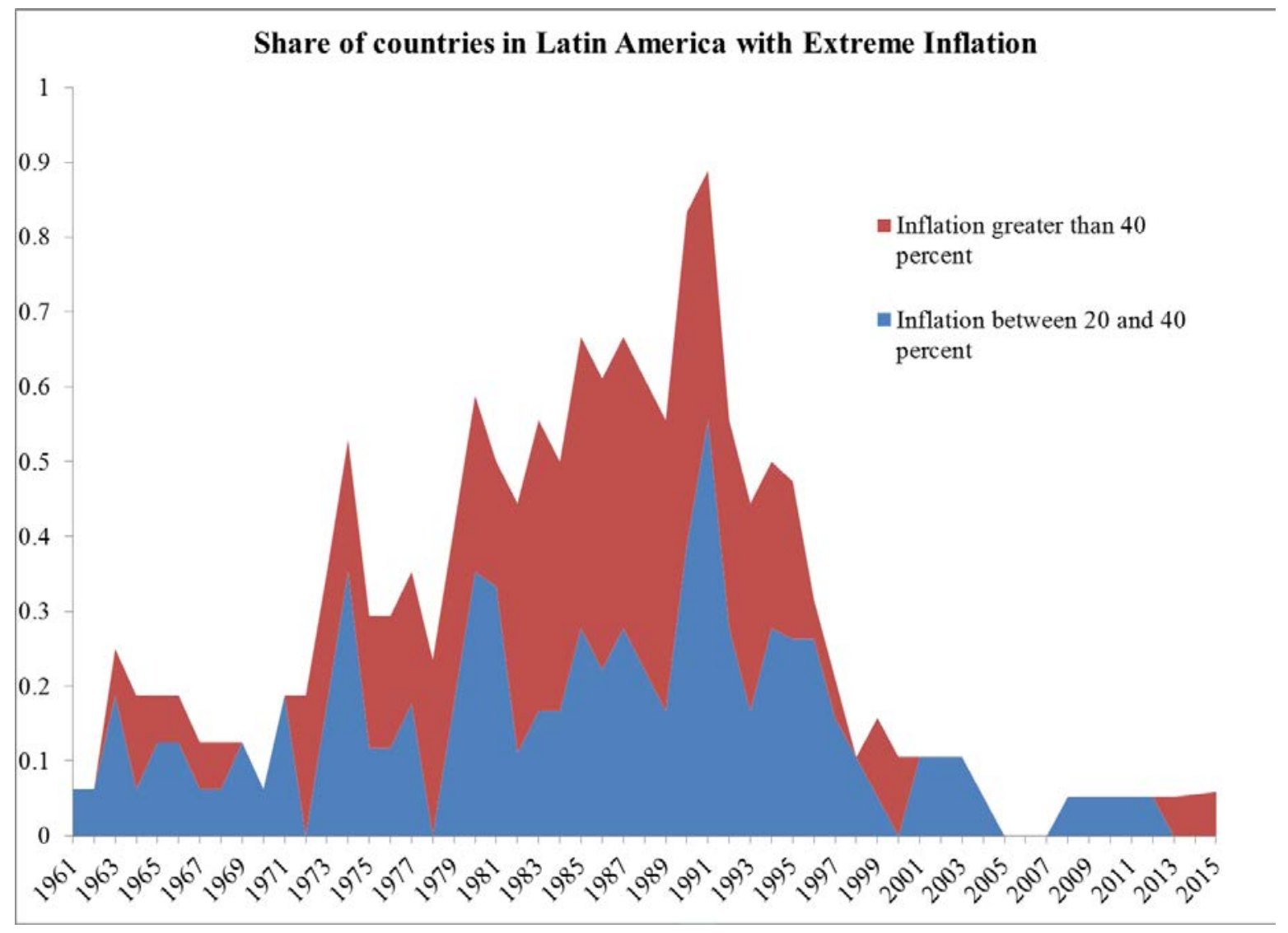

Figure 1b: Share of Latin American countries within each range of inflation outcomes

Latin America was the region most known for high inflation. Figure 1b shows almost all countries in the region in 1991 had inflation above 20 percent, and a substantial number above 40 percent. In the new millennium, these ranges of high inflation have largely disappeared. 


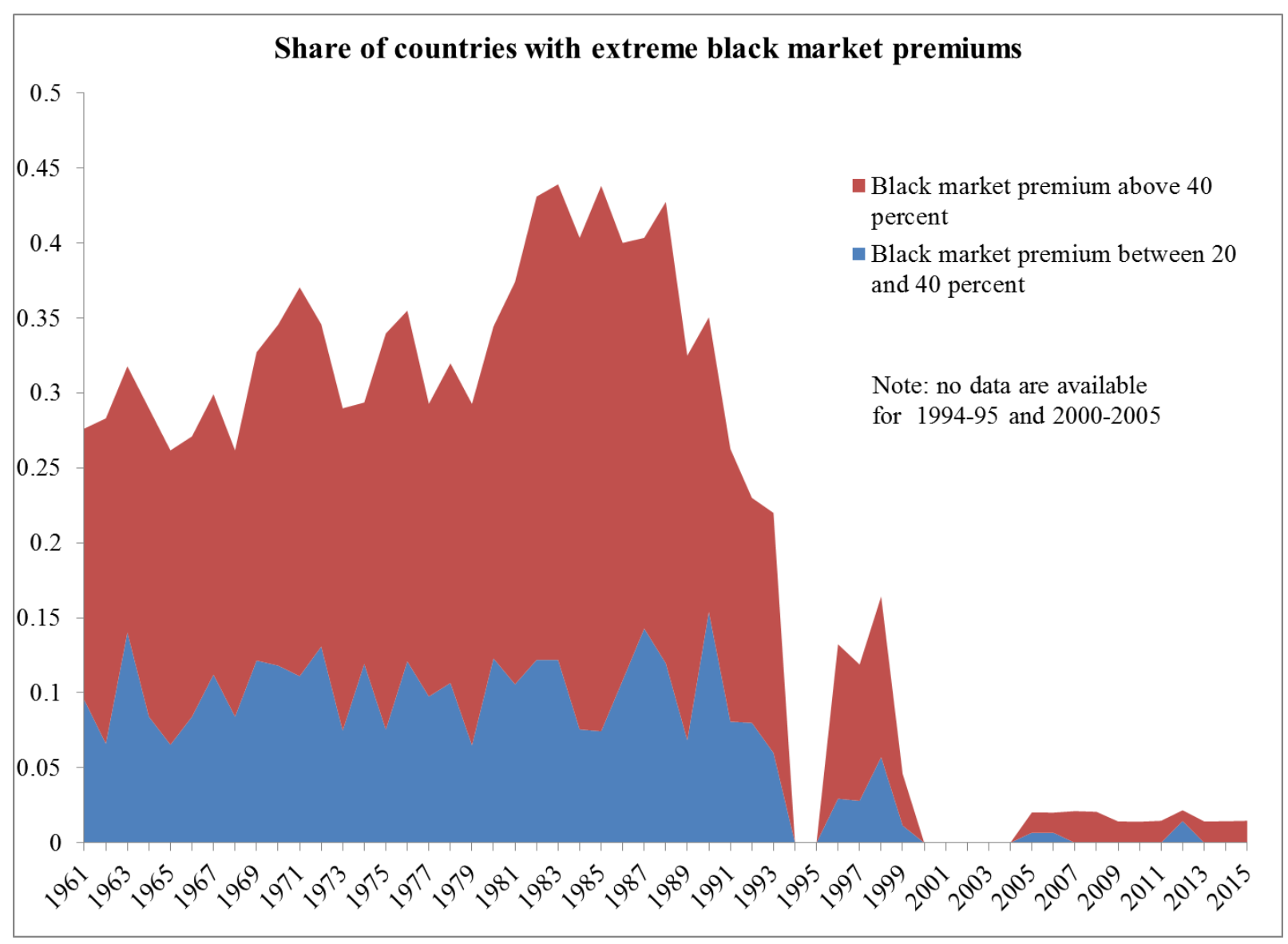

Figure 2a: Share of countries within each range of black market premium

As with inflation, Figure 2a shows there was some worsening of outcomes for the black market premium through the 1980s, reaching over 40 percent of countries with moderately or extremely bad outcomes -- another reason for reform advocacy beginning at that time. Beginning in the early 1990s, moderate and extreme black market premiums indeed began to diminish. In the new millennium, high black market premiums have mostly disappeared. (Note that the observations in 19941995 and 2000-2005 are not zeroes, they represent missing data.) 


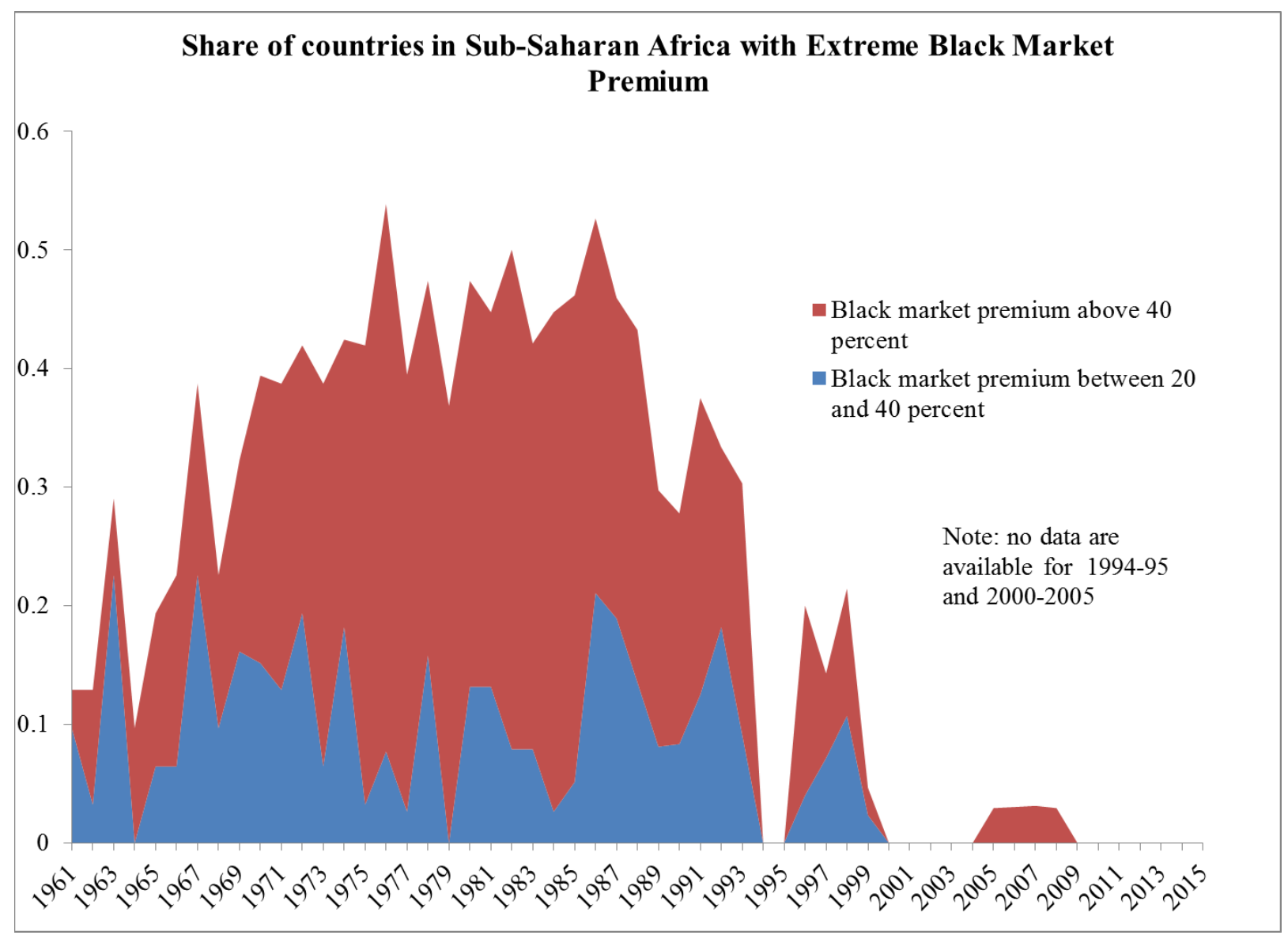

Figure 2b: Share of countries in Sub-Saharan Africa within each range of black market

If inflation was the characteristic policy problem of Latin America, a high black market premium was characteristic of Sub-Saharan Africa - reaching about 50 percent of countries in the 1980s. Figure $2 b$ shows the fall of such moderately and extremely bad policy outcomes in Africa. In the most recent years, no African countries have recorded black market premiums above 20 percent.

This striking revolution in policy outcomes is again one of the main results in this paper. Again, the reform process had not been complete with the onset of the doubts about reforms. 


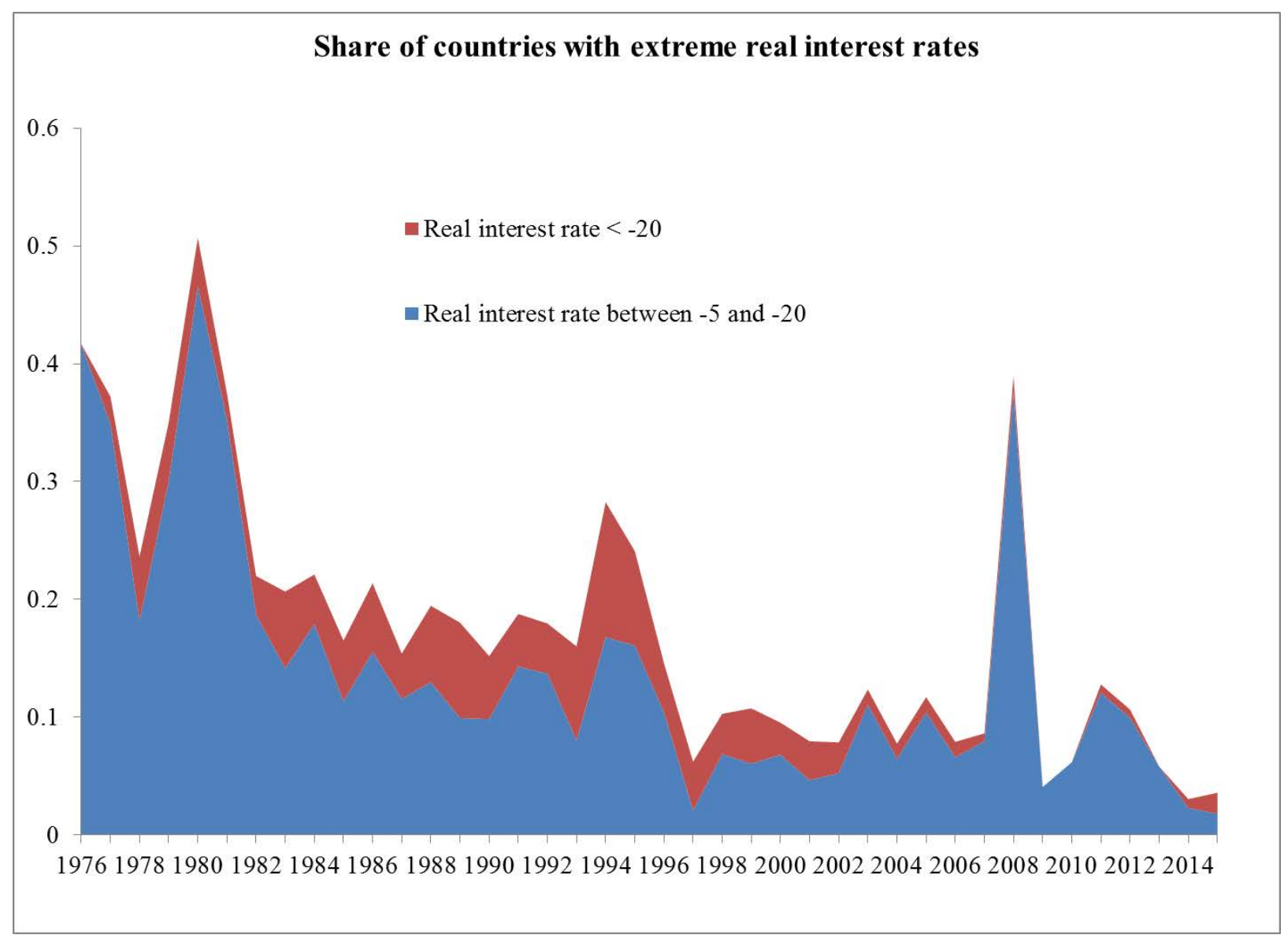

Figure 3: Share of countries within each range of negative real interest rates

Figure 3 shows the downward trend in extremely bad and moderately bad real interest rate outcomes, with the exception of a spike around the financial crisis in 2008. Data on real interest rates is sparser than other indicators. For example, there is not a sufficient sample to show data before 1976. 


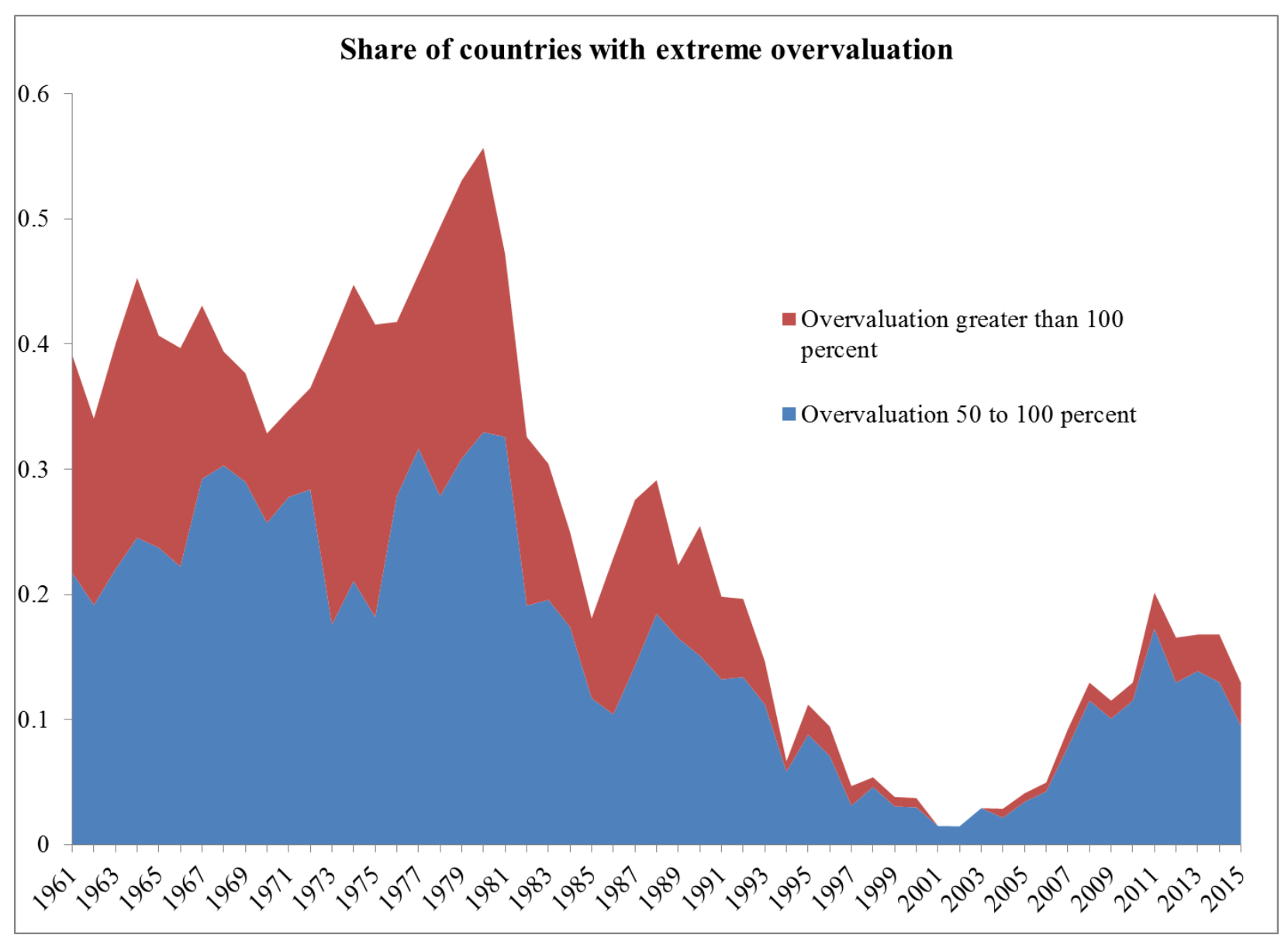

Figure 4: Share of countries within each range of overvaluation outcomes

Figure 4 shows a slightly different timing of bad policy outcomes for overvaluation compared to other outcomes. The worst outcomes were around 1980 and then showed steady improvement. Overvaluation in these ranges had mostly disappeared around 2002 and then has come back somewhat since. However, the 2008-2015 shares of bad outcomes are still below those of 1961-1980. 


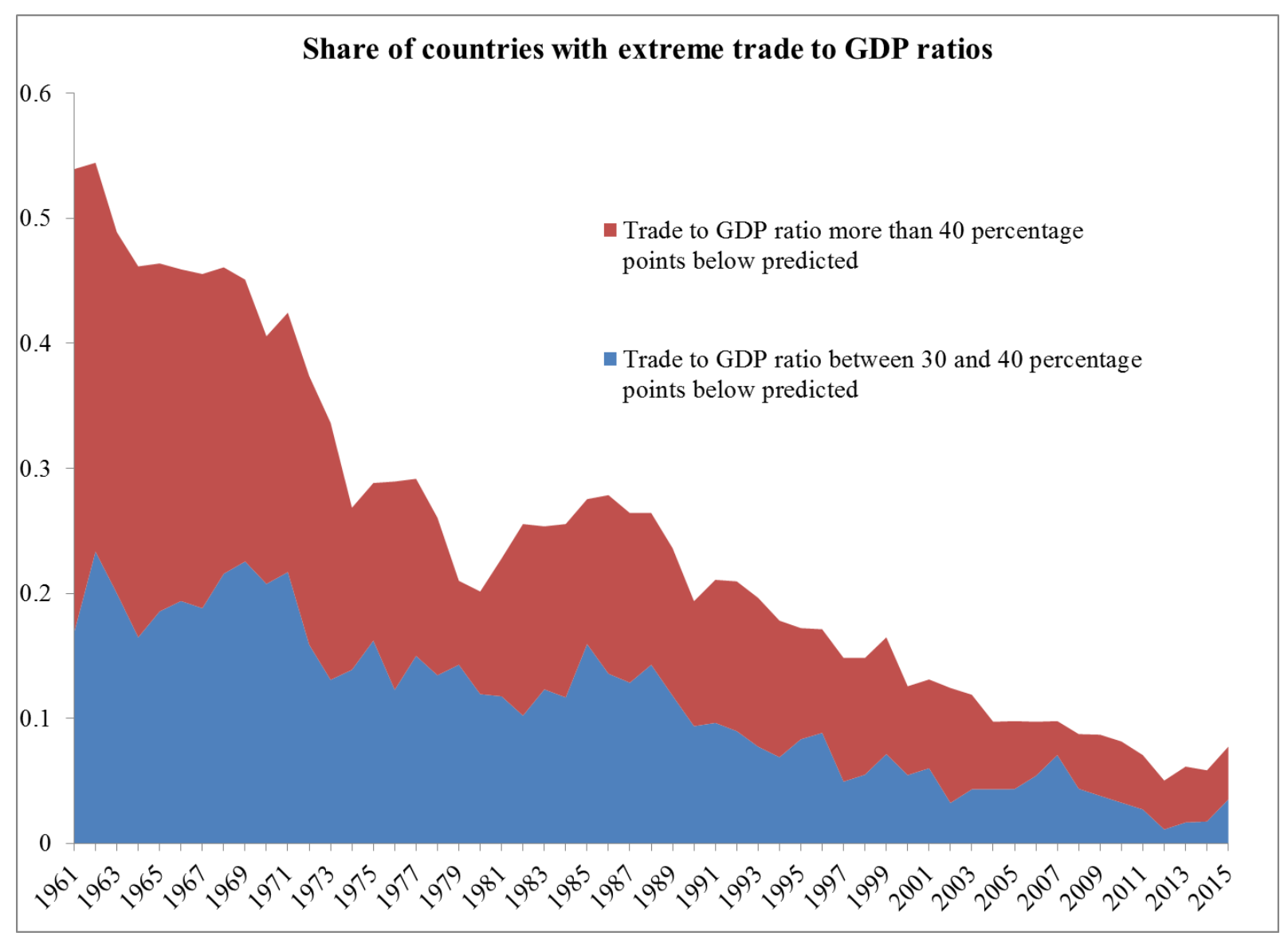

Figure 5: Share of countries by range of Trade to GDP ratios relative to Predicted trade share based on a pooled cross-section, time series regression of trade share on log population size, 1961-2015

Figure 5 shows the downward trend in abnormally low trade ratios over the entire period. As noted earlier, this is the index most distantly related to policy efforts. The trend shown here could reflect non-policy factors that increased trade worldwide, such as falling costs of transport and communication. In the regressions in the next section, year dummies will remove the global trend in the trade ratio as a possible determinant of growth changes. 


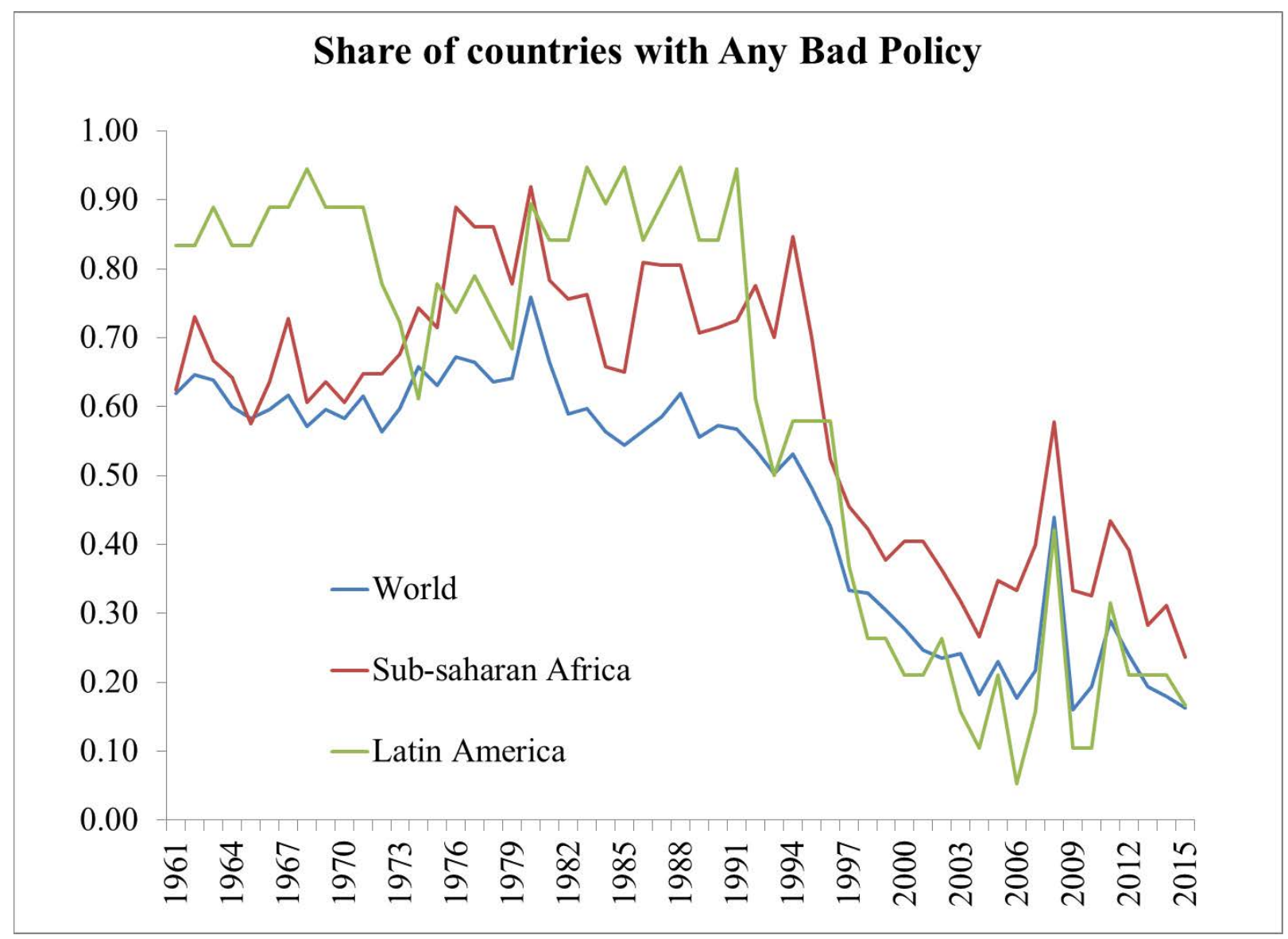

Figure 6: Share of countries with any extremely bad or moderately bad policy outcome

Figure 6 shows a summary measure of share of countries with any bad policy. Any bad policy is defined as having any of the moderate or extreme policy dummies set to one, with a minimum of 4 policy observations available for that country-year.

The summary measure shows a downward trend in bad policy outcomes worldwide, in Latin America, and in Sub-Saharan Africa. The sharpest break is around the mid-1990s, somewhat after the formulation of the Washington Consensus and the first negative reactions it received. 


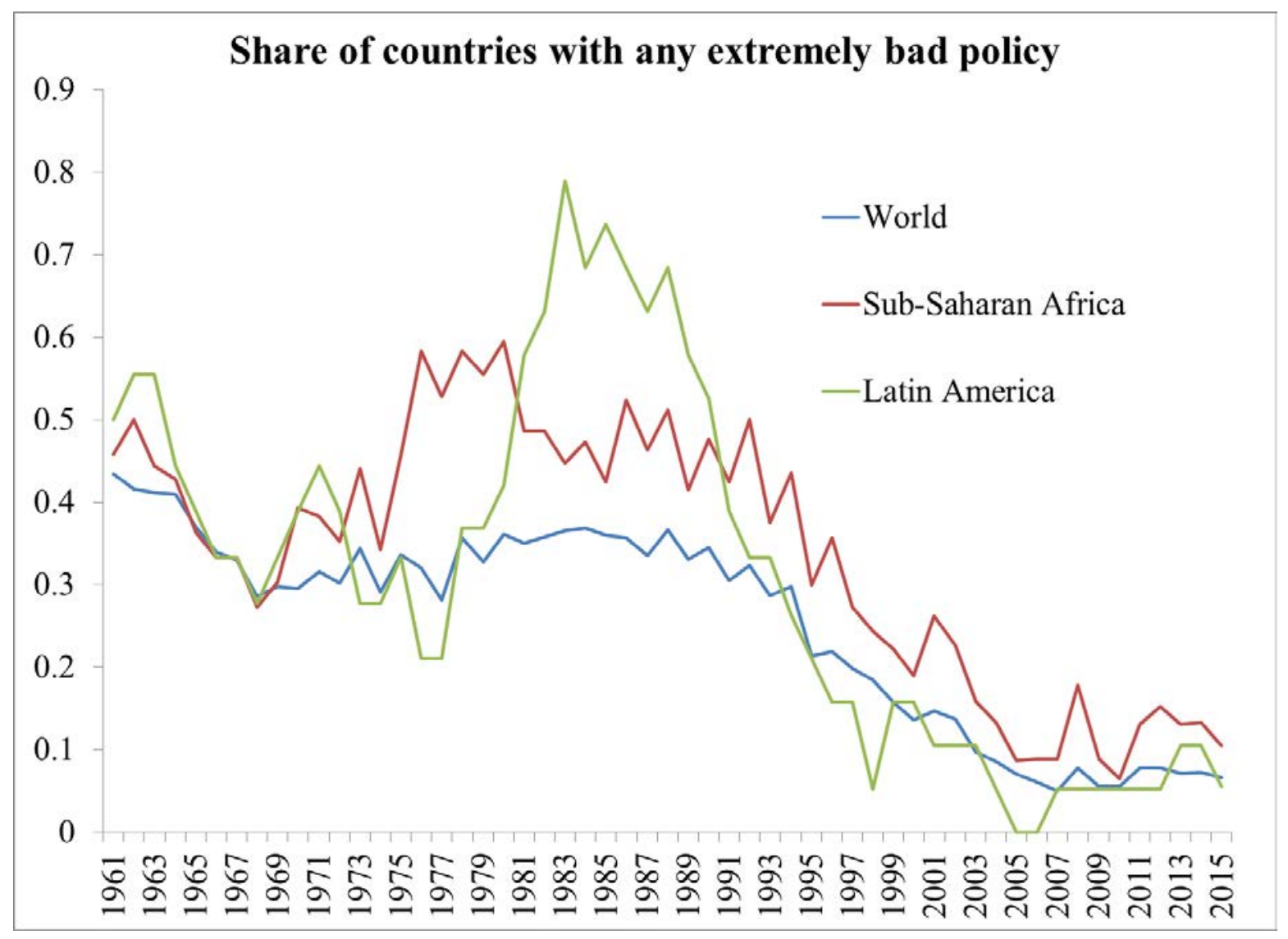

Figure 7: Share of countries with any extremely bad policy outcome

Figure 7 shows a similar graph to Figure 6, but now limited to extremely bad policy outcomes. It shows if any of the extremely bad policy dummies is set to one, for the sample with a minimum of at least two out of five policy outcomes available. The decline in the prevalence of any extreme policy is even more dramatic beginning in the early 1990s, going from surprisingly common (above 35 percent of countries up to the early 1990s) to almost non-existent for the world. The same pattern is even more striking for Africa and for Latin America.

Figures 6 and 7 alleviate a concern that the extreme policy ranges may be too extreme, such that no reasonable economist would be in favor of such extreme policy outcomes. This may be true or not, but the economic reform movement seems to deserve some credit for mostly doing away with extreme policy outcomes that were common up to and including the 1980s and early 1990s.

There is still the problem that these are endogenous policy outcomes that could reflect other factors besides policy changes. It is not obvious, however, what there 
is besides the economic reform movement that could have produced these common trends. Overall, the results in this section are suggestive of major policy reforms continuing and even accelerating in the new millennium. The early disappointment with reform in Africa and Latin America was arguably premature, both because not enough reform had happened and not enough post-reform growth data was available. Figures 6 and 7 could also be consistent with an exogenous international trend towards policy reform, although this cannot be resolved definitively.

\section{Correlations between policy outcomes and growth}

This section reviews evidence on whether the first stylized fact of improved policy outcomes can also be the basis of a second stylized fact of correlation between improved policy and growth outcomes.

\section{a. Overview}

Before doing the regression analysis, Table 2 starts with an illustrative overview of two types of countries - (1) those countries that had any extremely bad policies at any point in 1980-1998 and (2) those countries with no extremely bad policies at any point in 1980-1998. ${ }^{13}$

The first group of 92 countries had improved policy outcomes in 1999-2015, in line with the first stylized fact of the previous section -- strong global trends toward elimination of extreme policies. The second group of 52 countries had no such opportunity to eliminate extreme policies, because there were no extreme policies to eliminate.

\footnotetext{
${ }^{13}$ The period split is based on Easterly 2001. Moderately bad policies will be covered in the next subsection.
} 


\begin{tabular}{|c|c|c|c|c|}
\hline & \multicolumn{2}{|c|}{$\begin{array}{c}\text { Countries that had any extreme } \\
\text { policy 1980-1998 }\end{array}$} & \multicolumn{2}{|c|}{$\begin{array}{l}\text { Countries with no extreme policies } \\
1980-1998\end{array}$} \\
\hline & 1980-1998 & 1999-2015 & 1980-1998 & 1999-2015 \\
\hline Per Capita Growth & $0.7 \%$ & $2.1 \%$ & $2.3 \%$ & $1.7 \%$ \\
\hline \multicolumn{5}{|l|}{ Frequency of Policy Outcomes: } \\
\hline Black Market Premium Over 40 & $33.3 \%$ & $6.0 \%$ & $0.0 \%$ & $0.0 \%$ \\
\hline Inflation Over 40 & $16.7 \%$ & $2.0 \%$ & $0.0 \%$ & $0.0 \%$ \\
\hline Real Interest Rate Below -20 & $8.0 \%$ & $1.5 \%$ & $0.0 \%$ & $0.2 \%$ \\
\hline Overvaluation Over 100 Percent & $10.9 \%$ & $1.7 \%$ & $0.0 \%$ & $0.0 \%$ \\
\hline Residual Trade Share -40 Below Predicted & $19.0 \%$ & $7.4 \%$ & $0.0 \%$ & $3.9 \%$ \\
\hline Number of observations on per capita growth & 1603 & 1541 & 928 & 878 \\
\hline Number of countries & 92 & 92 & 52 & 52 \\
\hline
\end{tabular}

Table 2: Policy and growth outcomes for two types of countries - those that had any extreme policy in 1980-1998, and those that did not

Table 2 shows that countries that had the opportunity to reduce extreme policies did so, and also had average per capita growth increase by 1.4 percentage points from 1980-1998 to 1999-2015. Countries with no extreme policies to reduce saw growth fall by 0.5 percentage points between the same two periods.

To summarize, extreme policies in 1980-98 are a good predictor of subsequent reforms, accompanied by growth recovery. Of course, Table 2 does not resolve causality because it may have been growth outcomes driving policy outcomes. However, if the previous stylized fact of no growth improvements in policy reformers influenced beliefs on the failure of reform, the new stylized facts illustrated in Table 2 should update those beliefs.

\section{b. Baseline regressions}

To assess further the correlations between the policy dummies and growth, we want to remove any third factors that might generate spurious correlations between policies and growth.

First, the regressions of growth on policies will control for country fixed effects, which captures a wide range of the country's political, institutional, and economic variables that might affect growth, and at the same time might make countries more prone to bad policies.

As Easterly, Kremer, Pritchett, and Summers (1993) pointed out many years ago (replicated many times since -- see the summary in Pritchett, Sen, and Werker 
2017)), most of the candidate variables for growth determinants are highly persistent over time and hence would be mostly captured by fixed effects. For example, institutional variables were used to show some previous policy results to be non-robust (Rodrik and Rodriguez 2001, Easterly and Levine 2003). But country effects capture almost all of the variation in institutions, since they vary mostly in the cross-section dimension and little in the cross-time dimension. By controlling for country effects, the test here will be whether changes in growth are correlated with changes in policy within countries. Although there could be other growth determinants that are time-varying, we will control below for the most obvious ones - commodity price shocks and wars.

Second, the regressions control for year effects, removing spurious correlations possibly due to global shifts in the growth rate that may coincide with global shifts in policy outcomes.

The regressions assess the correlation of the growth outcome with the policy outcome in the same year. It is plausible that there could be a relation between growth and lagged policy outcomes, but it is difficult to know how to specify a complicated lag structure. Hence, this will be left for future research. 
Regressions of per capita growth on policy dummies, controlling for country and year effects, 1961-2015

\begin{tabular}{|c|c|c|c|c|c|c|}
\hline & (1) & (2) & (3) & (4) & (5) & (6) \\
\hline \multicolumn{7}{|l|}{ VARIABLES } \\
\hline \multirow[t]{2}{*}{$\begin{array}{l}\text { Dummy for Black } \\
\text { Market Premium } 20 \text { to } \\
40\end{array}$} & -0.00395 & $-0.00681 * *$ & & & & \\
\hline & $(0.00415)$ & $(0.00339)$ & & & & \\
\hline \multirow[t]{2}{*}{$\begin{array}{l}\text { Dummy for Black } \\
\text { Market Premium Over } \\
40\end{array}$} & $-0.00905^{* *}$ & $-0.0218 * * *$ & & & & \\
\hline & $(0.00432)$ & $(0.00291)$ & & & & \\
\hline \multirow[t]{2}{*}{$\begin{array}{l}\text { Dummy for Inflation } 20 \\
\text { to } 40\end{array}$} & $-0.0120 * * *$ & & $-0.0119 * * *$ & & & \\
\hline & $(0.00405)$ & & $(0.00272)$ & & & \\
\hline \multirow[t]{2}{*}{$\begin{array}{l}\text { Dummy for Inflation } \\
\text { Over } 40\end{array}$} & $-0.0266 * * *$ & & $-0.0415^{* * *}$ & & & \\
\hline & $(0.00558)$ & & $(0.00324)$ & & & \\
\hline \multirow[t]{2}{*}{$\begin{array}{l}\text { Dummy for Real Interest } \\
\text { Rate }-20 \text { to }-5\end{array}$} & 0.00140 & & & $-0.00648^{* * *}$ & & \\
\hline & $(0.00312)$ & & & $(0.00246)$ & & \\
\hline \multirow[t]{2}{*}{$\begin{array}{l}\text { Dummy for Real Interest } \\
\text { Rate Below -20 }\end{array}$} & -0.00706 & & & $-0.0336 * * *$ & & \\
\hline & $(0.00744)$ & & & $(0.00438)$ & & \\
\hline \multirow[t]{2}{*}{$\begin{array}{l}\text { Dummy for } \\
\text { Overvaluation } 50 \text { to } 100 \\
\text { percent }\end{array}$} & -0.00288 & & & & $-0.00762 * * *$ & \\
\hline & $(0.00302)$ & & & & $(0.00224)$ & \\
\hline \multirow[t]{2}{*}{$\begin{array}{l}\text { Dummy for } \\
\text { Overvaluation Over } 100 \\
\text { percent }\end{array}$} & $-0.0159 * * *$ & & & & $-0.0198 * * *$ & \\
\hline & $(0.00487)$ & & & & $(0.00325)$ & \\
\hline \multirow[t]{2}{*}{$\begin{array}{l}\text { Dummy for Residual } \\
\text { Trade Share }-40 \text { to }-30 \\
\text { Below Predicted }\end{array}$} & $-0.0114 * * *$ & & & & & $-0.00660 * *$ \\
\hline & $(0.00384)$ & & & & & $(0.00270)$ \\
\hline \multirow[t]{2}{*}{$\begin{array}{l}\text { Dummy for Residual } \\
\text { Trade Share }-40 \text { Below } \\
\text { Predicted }\end{array}$} & $-0.0226 * * *$ & & & & & $-0.0148 * * *$ \\
\hline & $(0.00470)$ & & & & & $(0.00301)$ \\
\hline Observations & 2,442 & 5,403 & 6,760 & 4,806 & 5,250 & 7,695 \\
\hline R-squared & 0.156 & 0.075 & 0.087 & 0.083 & 0.081 & 0.061 \\
\hline Number of countries & 129 & 189 & 178 & 170 & 146 & 192 \\
\hline \multicolumn{7}{|c|}{ Standard errors in parentheses } \\
\hline$* * * \mathrm{p}<0.01, * * \mathrm{p}<0.05$, * & $p<0.1$ & & & & & \\
\hline
\end{tabular}

Table 3: Baseline regression of growth on bad policy dummies, controlling for country and year effects 
When each policy is entered one at a time in columns (2) through (6) of Table 3 with two dummies each for extremely bad policy outcome and moderately bad policy outcome - all policy dummies are significant. The magnitude of the association with growth is large, with growth shifting downward between half a percentage point to over four percentage points, depending on the different kinds and degrees of bad policy outcomes.

Note however that the R-squared is low for these regressions. This reminds us that there are many shocks in annual growth data that makes it difficult to distinguish any signal of reform effect from noise in any given year for any given country. Some of the doubts about the efficacy of reforms for growth could arise for observers of individual reforming countries where noise produces a bad growth outcome despite a major reform. (Some shocks could be observable, like the wars and commodity price shocks we address below.)

Column (1) controls for all policies at once, which makes the sample much smaller. Extremely bad outcomes for the black market premium, inflation, overvaluation, and the trade share are still all significantly correlated with growth. Negative real interest rates are not significant, even for the extreme of less than -20 percent. The magnitudes of the growth shifts with extremely bad policies are still large, between 1 and 3 percentage points.

Moderately bad policy outcomes on inflation and the trade ratio are also significant in column (1) controlling for all other policies. The negative correlation of growth of with inflation in the 20 to 40 percent range seems to contradict Bruno and Easterly 1996, who found inflation in this range to be insignificantly correlated with growth (without any other controls). However, we will see that these results on this and other moderately bad policies are not very robust.

The other moderately bad policy significant in the full regression (1) is the low trade share in the region of 30 to 40 percentage points below the trade share predicted by population size.

The other three policies do not have a significant association with growth in the moderately bad range in the full regression (1). As with the previous literature, 
there is less evidence for a negative effect of moderately bad policies than there is for extremely bad policies. ${ }^{14}$

\section{c. Controlling for wars and commodity prices}

There are also some observable time-varying country-specific shocks that could generate spurious correlations between policy and growth outcomes. Among the most obvious ones are civil wars and export price booms and busts. To test this possibility, this paper uses data on civil wars and export price shocks from Bazzi and Blattman 2014.

The Bazzi and Blattman data on civil wars are from a standard source, the data collected by a collaboration of the Uppsala Conflict Data Program (UCDP) and the Peace Research Institute Oslo (PRIO). ${ }^{15}$ The variable used here takes the value one for any civil war in any country-year with at least 25 battle deaths, and zero otherwise.

Bazzi and Blattman also collected data on 65 commodities exported by countries in Latin America, Africa, the Middle East, and Asia from 1957 to 2007. They defined the commodity export price shock as the geometric average of log change in international prices weighted by lagged share of each commodity in exports. The average price change is interacted with the share of commodity exports in GDP, measured at the mid-point of the period.

\footnotetext{
${ }^{14}$ Sometimes such insignificance is over-interpreted as implying the definite conclusion "moderately bad policies don't matter," which of course does not follow either. One issue is the low power of regression (1) compared to the larger samples of regressions (2) through (6). One way to explore this is to restrict the sample for regressions (2) through (6) to be the same as the smaller sample in (1). Appendix Table 1 gives these new regressions for columns (2) through (6), which show moderate ranges of the black market premium, negative real interest rates, and overvaluation are insignificant in the smaller sample, in contrast to the significant results for larger samples for such moderately bad policy ranges in columns (2) through (6) of Table 3. These results are suggestive that the smaller sample in column (1) of Table 3 may be partly to blame for the insignificance of moderate policy variables, which should induce caution about overinterpreting insignificant coefficients as if they were zero coefficients. On the other hand, it remains true that the main robust correlations between growth and policy outcomes are for the extreme policy outcomes.

${ }^{15}$ https://www.prio.org/Data/Armed-Conflict/UCDP-PRIO/
} 
Regressions of per capita growth on war, commodity price shocks, and policy outcome variables

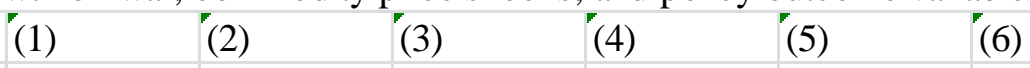

\begin{tabular}{|c|c|c|c|c|c|c|}
\hline Dummy for Any Civil War & $\begin{array}{l}-0.00777^{*} \\
(0.00420)\end{array}$ & $\begin{array}{l}-0.0126 * * * \\
(0.00382)\end{array}$ & $\begin{array}{l}-0.0133^{* * *} \\
(0.00308)\end{array}$ & $\begin{array}{l}-0.0104 * * * \\
(0.00351)\end{array}$ & $\begin{array}{l}-0.0132 * * * \\
(0.00300)\end{array}$ & $\begin{array}{l}-0.0188 * * * \\
(0.00312)\end{array}$ \\
\hline $\begin{array}{l}\text { Export Commodity Price } \\
\text { Shock }\end{array}$ & $\begin{array}{l}0.00221 \\
(0.00158)\end{array}$ & $\begin{array}{l}0.000804 \\
(0.00149)\end{array}$ & $\begin{array}{l}0.00239 * * \\
(0.00112)\end{array}$ & $\begin{array}{l}0.00216^{*} \\
(0.00113)\end{array}$ & $\begin{array}{l}0.00174 \\
(0.00119)\end{array}$ & $\begin{array}{l}0.00198^{*} \\
(0.00113)\end{array}$ \\
\hline $\begin{array}{l}\text { Dummy for Black Market } \\
\text { Premium } 20 \text { to } 40\end{array}$ & -0.00400 & -0.00500 & & & & \\
\hline $\begin{array}{l}\text { Dummy for Black Market } \\
\text { Premium Over } 40\end{array}$ & $\begin{array}{l}(0.00484) \\
-0.0114^{* *}\end{array}$ & $(0.00426)$ & & & & \\
\hline & $(0.00529)$ & $(0.00372)$ & & & & \\
\hline Dummy for Inflation 20 to 40 & $-0.00887^{*}$ & & $-0.00935^{* * *}$ & & & \\
\hline & $(0.00493)$ & & $(0.00339)$ & & & \\
\hline Dummy for Inflation Over 40 & $\begin{array}{l}-0.0277 * * * \\
(0.00710)\end{array}$ & & $\begin{array}{l}-0.0339 * * * \\
(0.00409)\end{array}$ & & & \\
\hline $\begin{array}{l}\text { Dummy for Real Interest } \\
\text { Rate }-20 \text { to }-5\end{array}$ & -0.00102 & & & $-0.00530 *$ & & \\
\hline & $(0.00406)$ & & & $(0.00298)$ & & \\
\hline $\begin{array}{l}\text { Dummy for Real Interest } \\
\text { Rate Below }-20\end{array}$ & 0.000293 & & & $-0.0235^{* * *}$ & & \\
\hline & $(0.00913)$ & & & $(0.00486)$ & & \\
\hline $\begin{array}{l}\text { Dummy for Overvaluation } 50 \\
\text { to } 100 \text { percent }\end{array}$ & -0.00268 & & & & $-0.00767 * *$ & \\
\hline & $(0.00444)$ & & & & $(0.00310)$ & \\
\hline $\begin{array}{l}\text { Dummy for Overvaluation } \\
\text { Over } 100 \text { percent }\end{array}$ & $-0.0122^{* *}$ & & & & $-0.0219 * * *$ & \\
\hline & $(0.00602)$ & & & & $(0.00410)$ & \\
\hline $\begin{array}{l}\text { Dummy for Residual Trade } \\
\text { Share }-40 \text { to }-30 \text { Below } \\
\text { Predicted }\end{array}$ & $-0.0116^{* *}$ & & & & & $-0.00793 * *$ \\
\hline & $(0.00530)$ & & & & & $(0.00330)$ \\
\hline $\begin{array}{l}\text { Dummy for Residual Trade } \\
\text { Share -40 Below Predicted }\end{array}$ & $-0.0230 * * *$ & & & & & $-0.0103 * * *$ \\
\hline & $(0.00636)$ & & & & & $(0.00385)$ \\
\hline Observations & 1,341 & 3,117 & 3,611 & 2,431 & 3,061 & 4,184 \\
\hline R-squared & 0.147 & 0.063 & 0.086 & 0.091 & 0.081 & 0.064 \\
\hline Number of countries & 88 & 114 & 110 & 104 & 97 & 115 \\
\hline Standard errors in parentheses & $\mathrm{s} * * * \mathrm{p}<0.01$ & , ** $\mathrm{p}<0.05$ & $* \mathrm{p}<0.1$ & & & \\
\hline
\end{tabular}

Table 4: Regression of growth on policy dummies controlling for country effects, year effects, civil wars, and export price shocks 
Table 4 shows the results of adding controls for wars and export price shocks. The civil war dummy itself usually shows a significant correlation with negative growth outcomes. The export price shock rarely has a significant effect on growth. The R-squared of these regressions remain low, confirming the difficulties in the previous literature at explaining a large share of the within-country variation in growth rates.

Controlling for wars and export price shocks, the results are mostly similar to the previous table without such controls. In columns (2) through (6) controlling for one policy at a time at "moderate" and "extreme” levels, all policy dummies are still significant except for moderate black market premiums and moderately negative real interest rates.

For the full regression (1) with all controls simultaneously, the same four extreme policy outcomes are still significant after controlling for wars and export price shocks - the black market premium, inflation, overvaluation, and low trade shares. The magnitudes of the coefficients are broadly similar.

The main change from the previous regression without wars and price shocks is that moderately bad inflation is now only marginally significant at the 10 percent level compared to its previous significance at the 1 percent level. The only moderately bad policy to be significant in Column (1) is moderately low trade shares. ${ }^{16}$

The main robust result from all regressions is that extreme values for four out of five policy outcomes have a significant negative association with growth. Only one out of the five moderately bad policy outcomes is robustly significant in all regressions.

\footnotetext{
${ }^{16}$ As before, it is important to respect the absence of robust evidence that most moderately bad policies matter, while at the same time not overstating the result to imply definite proof that "moderately bad policies don't matter." A relevant issue is again the reduction in sample caused by using the wars and commodity price shock data. Appendix Table 2 does a test to re-run the regressions in Table 4 at the same, smaller samples compared to Table 3, but using the Table 3 specifications without controlling for wars and commodity price shocks. ${ }^{16}$ The same pattern of insignificance emerges - the insignificance of moderate inflation in column (1) and insignificance of moderate black market premium and moderate negative real interest rates in columns (2) through (6). The changes in significant results from Table 3 to Table 4 seem to be partly due to the reduction in samples rather than the controls for wars and commodity prices per se.
} 
The Appendix Section 2 evaluates the robustness of the results for alternative upward or downward ranges for extremely bad or moderate bad policies. It shows the results on extreme policies are mostly robust to alternative higher or lower thresholds (in absolute value) for what is defined as extreme. The results on moderate policies are mostly robust to upward adjustment (in absolute value terms) but not very robust to downward adjustment of the ranges. Refining the definition of moderately bad policy to be even more moderate weakens the results further on moderate policies affecting growth. This result partially replicates Easterly (2005b), which found that extremely bad policies are significantly associated with bad growth outcomes, but found little such evidence for moderately bad policies.

\section{Latin America and Africa since the "Lost Decades"}

We next do a calibration of how much the reforms could potentially explain the recovery of Latin America and Africa from the "lost decades" of the 1980s and 1990s to better growth performance since. We use the 1980-98 timing for the "lost decades” paper from Easterly (2001). We apply the coefficients from the baseline regression in column (1) of Table 3 to the change in prevalence of extremely bad and moderately bad policies in Africa and Latin America from 1980-98 to 19992015. 
a. How much does reform explain recovery from the "lost decades"?

\begin{tabular}{|c|c|c|c|c|}
\hline & $\begin{array}{l}\text { Africa } 1980- \\
98\end{array}$ & $\begin{array}{l}\text { Africa 1999- } \\
2015\end{array}$ & $\begin{array}{l}\text { Actual Africa } \\
\text { growth } \\
\text { change }\end{array}$ & $\begin{array}{l}\text { Predicted } \\
\text { Africa growth } \\
\text { change }\end{array}$ \\
\hline Per Capita Growth & $0.1 \%$ & $1.8 \%$ & $1.76 \%$ & $1.27 \%$ \\
\hline \multicolumn{5}{|l|}{ Frequency of Policy Outcomes: } \\
\hline Black Market Premium Over 40 & $27.5 \%$ & $3.7 \%$ & & $0.22 \%$ \\
\hline Black Market Premium 20 to 40 & $10.8 \%$ & $0.7 \%$ & & $0.04 \%$ \\
\hline Inflation Over 40 & $14.6 \%$ & $3.0 \%$ & & $0.31 \%$ \\
\hline Inflation 20 to 40 & $15.3 \%$ & $4.9 \%$ & & $0.13 \%$ \\
\hline Real Interest Rate Below -20 & $9.2 \%$ & $2.2 \%$ & & $0.05 \%$ \\
\hline Real Interest Rate -20 to -5 & $20.1 \%$ & $8.9 \%$ & & $-0.02 \%$ \\
\hline Overvaluation Over 100 percent & $15.0 \%$ & $4.1 \%$ & & $0.17 \%$ \\
\hline Overvaluation 50 to 100 percent & $20.2 \%$ & $10.1 \%$ & & $0.03 \%$ \\
\hline $\begin{array}{l}\text { Residual Trade Share - } 40 \text { Below } \\
\text { Predicted }\end{array}$ & $19.0 \%$ & $8.1 \%$ & & $0.25 \%$ \\
\hline $\begin{array}{l}\text { Residual Trade Share }-40 \text { to - } 30 \text { Below } \\
\text { Predicted }\end{array}$ & $15.0 \%$ & $6.5 \%$ & & $0.10 \%$ \\
\hline
\end{tabular}

Table 5a: Changes in policy outcomes from 1980-98 to 1999-2015 for Africa and predicted growth changes (Coefficients for predicted growth from core regression controlling for all policies and country and year effects)

Table 5a shows in the first two columns the average prevalence in 1980-98 and 1999-2015 of the moderately and extremely bad policies for Africa. As already noted in Section 3, there were major decreases in the prevalence of bad policy outcomes in Africa.

Row (1) shows the average per capita growth outcome in Africa for the two regions. Column (4) shows the predicted changes in average growth from 1980-98 to 1999-2015 for the two regions by applying the regression coefficients to the changes in each row in columns (5) and (6). The predicted change in growth (1.3 percentage points) is lower than the actual change in growth (1.8 percentage points), but still substantial. The elimination of extreme policies on the black market premium, inflation, overvaluation, and low trade share explain most of the predicted increase in growth. 


\begin{tabular}{|c|c|c|c|c|}
\hline & $\begin{array}{l}\text { Latin } \\
\text { America } \\
\text { 1980-98 }\end{array}$ & $\begin{array}{l}\text { Latin } \\
\text { America } \\
\text { 1999-2015 }\end{array}$ & $\begin{array}{l}\text { Actual Latin } \\
\text { America } \\
\text { growth } \\
\text { change }\end{array}$ & $\begin{array}{l}\text { Predicted } \\
\text { Latin } \\
\text { America } \\
\text { growth } \\
\text { change }\end{array}$ \\
\hline Per Capita Growth & $0.4 \%$ & $2.1 \%$ & $1.67 \%$ & $1.74 \%$ \\
\hline \multicolumn{5}{|l|}{ Frequency of Policy Outcomes: } \\
\hline Black Market Premium Over 40 & $24.9 \%$ & $7.4 \%$ & & $0.16 \%$ \\
\hline Black Market Premium 20 to 40 & $15.9 \%$ & $1.6 \%$ & & $0.06 \%$ \\
\hline Inflation Over 40 & $27.5 \%$ & $2.2 \%$ & & $0.67 \%$ \\
\hline Inflation 20 to 40 & $24.9 \%$ & $4.1 \%$ & & $0.25 \%$ \\
\hline Real Interest Rate Below -20 & $10.9 \%$ & $2.3 \%$ & & $0.06 \%$ \\
\hline Real Interest Rate -20 to -5 & $13.5 \%$ & $9.6 \%$ & & $-0.01 \%$ \\
\hline Overvaluation Over 100 percent & $4.8 \%$ & $0.7 \%$ & & $0.06 \%$ \\
\hline Overvaluation 50 to 100 percent & $8.3 \%$ & $4.1 \%$ & & $0.01 \%$ \\
\hline Residual Trade Share -40 Below Predicted & $17.7 \%$ & $2.5 \%$ & & $0.34 \%$ \\
\hline $\begin{array}{l}\text { Residual Trade Share - } 40 \text { to - } 30 \text { Below } \\
\text { Predicted }\end{array}$ & $14.9 \%$ & $3.8 \%$ & & $0.13 \%$ \\
\hline
\end{tabular}

Table 5b: Changes in policy outcomes from 1980-98 to 1999-2015 for Latin America and predicted growth changes (Coefficients for predicted growth from core regression controlling for all policies and country and year effects)

Table $5 \mathrm{~b}$ does the same exercise for Latin America. The predicted change in growth (1.7 percentage points) in Latin America from the reduced prevalence of bad policy outcomes slightly exceeds the actual change in Latin American growth from 1980-98 to 1999-2015. Correcting extreme and moderate inflation, an extremely low trade share, and extreme black market premiums explains most of the predicted growth increase in Latin America.

Although these results are still not causal, Tables $5 \mathrm{a}$ and $5 \mathrm{~b}$ are suggestive that policy reforms could explain recovery from the Lost Decades in Africa and Latin America.

b. Why did the earlier literature conclude reforms were disappointing?

One way of relating these new results to the pessimistic conclusions of the old literature is to compare results obtained with old data to the results in this paper. This could be done by applying new data to the specifications of papers in the old literature. However, there were many different specifications in the various papers 
and this would quickly become unwieldy - and so this paper did not try that approach.

This paper instead takes the simple specifications here and applies them to the old database available to the earlier papers. As above, the breakpoint will be taken to be 1998. An old database covering those years is available from the Global Development Network Growth Database, posted on a World Bank website in 2001 and never updated since. ${ }^{17}$ Table 6 shows the baseline specifications of Table 3 applied to this old database.

\begin{tabular}{|c|c|c|c|c|c|c|}
\hline Regressions of per capita growth on $\mathrm{p}$ & $\begin{array}{r}\text { olicy dummi } \\
1\end{array}$ & $\begin{array}{l}\text {, controlli } \\
62-98\end{array}$ & for coun & y and yea & effects, ol & database \\
\hline & $(1)$ & $(2)$ & $(3)$ & (4) & (5) & $(6)$ \\
\hline Dummy variables for policy outcome ranges: & & & & & & \\
\hline Black Market Premium 20 to 40 & -0.00362 & $-0.00744 * *$ & & & & \\
\hline & $(0.00548)$ & $(0.00360)$ & & & & \\
\hline Black Market Premium Over 40 & -0.00657 & $-0.0227 * * *$ & & & & \\
\hline & $(0.00573)$ & $(0.00325)$ & & & & \\
\hline Inflation 20 to 40 & $-0.0113 * *$ & & $-0.0112 * * *$ & & & \\
\hline & $(0.00487)$ & & $(0.00304)$ & & & \\
\hline Inflation Over 40 & $-0.0171^{* *}$ & & $-0.0369 * * *$ & & & \\
\hline & $(0.00762)$ & & $(0.00391)$ & & & \\
\hline Real Interest Rate -20 to -5 & 0.00235 & & & -0.00492 & & \\
\hline & $(0.00560)$ & & & $(0.00458)$ & & \\
\hline Real Interest Rate Below -20 & -0.0130 & & & $-0.0283 * * *$ & & \\
\hline & $(0.00995)$ & & & $(0.00683)$ & & \\
\hline Overvaluation 50 to 100 percent & 0.000448 & & & & 0.00293 & \\
\hline & $(0.00465)$ & & & & $(0.00313)$ & \\
\hline Overvaluation Over 100 percent & $-0.0261 * * *$ & & & & $-0.00856^{*}$ & \\
\hline & $(0.00717)$ & & & & $(0.00463)$ & \\
\hline Residual Trade Share -40 to -30 Below Predicted & $0.0174 *$ & & & & & -0.00485 \\
\hline & $(0.00894)$ & & & & & $(0.00392)$ \\
\hline Residual Trade Share -40 Below Predicted & $0.0268 * * *$ & & & & & -0.00372 \\
\hline & $(0.00998)$ & & & & & $(0.00476)$ \\
\hline Country Effects & YES & YES & YES & YES & YES & YES \\
\hline Year Effects & YES & YES & YES & YES & YES & YES \\
\hline Observations & 1,412 & 3,643 & 3,986 & 2,477 & 3,305 & 4,643 \\
\hline R-squared & 0.102 & 0.069 & 0.084 & 0.079 & 0.062 & 0.054 \\
\hline Number of countries & 92 & 159 & 159 & 156 & 105 & 177 \\
\hline Standard errors in parentheses & $* * * \mathrm{p}<0.01, * *$ & $<0.05, * \mathrm{p}<0$ & & & & \\
\hline
\end{tabular}

Table 6: Baseline specifications from Table 3 applied to old database 1962-1998

While some coefficients are still significant, the results are weaker compared to those including the recent data. When entering policies one at a time in columns

\footnotetext{
${ }^{17}$ This author created the database together with Mirvat Sewadeh at the World Bank. It was not updated since this author left the World Bank in 2001. The database runs through 1999, but 1998 is the breakpoint chosen for the reasons given earlier.
} 
(2) through (6), 5 out of 10 coefficients are significant (compared to all 10 being significant with the full database). Overvaluation and Low Trade Share fail to be significant.

Entering all policy variables at once in column 1, the extreme black market premium dummy loses the statistical significance it had in the full database. Extremely Low Trade Share is significant, but with the opposite of the expected sign such that repressed trade appears to be good for growth. The old dataset shows a weaker and more ambiguous picture for the growth payoffs associated with reform outcomes.

Tables 7a and 7b redo the policy and growth accounting exercise of Tables $5 \mathrm{a}$ and $5 \mathrm{~b}$ for the old dataset 1962-98. To measure reform within the period with a timing to match the advent of the Washington Consensus, we split the period 1980-98 in half and compare the first and second half.

\begin{tabular}{|c|c|c|c|c|}
\hline $\begin{array}{l}\text { Reforms and growth in Sub- } \\
\text { Saharan Africa }\end{array}$ & average $80-88$ & average 89-98 & $\begin{array}{l}\text { Actual growth } \\
\text { change }\end{array}$ & $\begin{array}{l}\text { Predicted growth } \\
\text { change from } \\
\text { policy reform }\end{array}$ \\
\hline Per capita growth & $-0.4 \%$ & $0.3 \%$ & $0.7 \%$ & $0.0 \%$ \\
\hline \multicolumn{5}{|l|}{ Frequency of policy ranges: } \\
\hline Black Market Premium Over 40 & $35 \%$ & $18 \%$ & & $0.1 \%$ \\
\hline Black Market Premium 20 to 40 & $11 \%$ & $10 \%$ & & $0.0 \%$ \\
\hline Inflation Over 40 & $11 \%$ & $17 \%$ & & $-0.1 \%$ \\
\hline Inflation 20 to 40 & $16 \%$ & $14 \%$ & & $0.0 \%$ \\
\hline Real Interest Rate Below -20 & $7 \%$ & $5 \%$ & & $0.0 \%$ \\
\hline Real Interest Rate -20 to -5 & $11 \%$ & $8 \%$ & & $0.0 \%$ \\
\hline Overvaluation Over 100 percent & $15 \%$ & $10 \%$ & & $0.1 \%$ \\
\hline Overvaluation 50 to 100 percent & $26 \%$ & $11 \%$ & & $0.0 \%$ \\
\hline $\begin{array}{l}\text { Residual Trade Share - } 40 \text { Below } \\
\text { Predicted }\end{array}$ & $11 \%$ & $8 \%$ & & $-0.1 \%$ \\
\hline $\begin{array}{l}\text { Residual Trade Share }-40 \text { to }-30 \\
\text { Below Predicted }\end{array}$ & $11 \%$ & $6 \%$ & & $-0.1 \%$ \\
\hline
\end{tabular}

Table 7a: Changes in policy outcomes from 1980-88 to 1989-1998 for Africa and predicted growth changes (Coefficients for predicted growth from core regression in column 1 of Table 6 controlling for all policies and country and year effects)

Table 7a shows that the increase in growth in Africa from 1980-88 to 1989-98 was modest, and policy reform fails to predict any part of this increase. The difference from Table 5a comes from two sources - how much there is reform, and what is 
the predicted growth with this reform. With the extreme black market premiums, there is reform but the Table 6 estimate shows little payoff for growth. With inflation, Table 6 showed a growth payoff with better inflation outcomes but Table 7a shows no progress in Africa during this period on extreme or moderate inflation. The other policies show a combination of both factors, of not much reform and not much evidence of reforms paying off for growth.

\begin{tabular}{|c|c|c|c|c|}
\hline $\begin{array}{l}\text { Reforms and growth in Latin } \\
\text { America }\end{array}$ & avg 80-88 & avg 89-98 & $\begin{array}{l}\text { Actual growth } \\
\text { change }\end{array}$ & $\begin{array}{r}\text { Predicted } \\
\text { growth change } \\
\text { from policy } \\
\text { reform }\end{array}$ \\
\hline Per capita growth & $-1.1 \%$ & $1.5 \%$ & $2.5 \%$ & $0.0 \%$ \\
\hline \multicolumn{5}{|l|}{ Frequency of policy ranges: } \\
\hline Black Market Premium Over 40 & $42.5 \%$ & $5.2 \%$ & & $0.2 \%$ \\
\hline Black Market Premium 20 to 40 & $19 \%$ & $12 \%$ & & $0.0 \%$ \\
\hline Inflation Over 40 & $34 \%$ & $22 \%$ & & $0.2 \%$ \\
\hline Inflation 20 to 40 & $24 \%$ & $27 \%$ & & $0.0 \%$ \\
\hline Real Interest Rate Below -20 & $12 \%$ & $8 \%$ & & $0.1 \%$ \\
\hline Real Interest Rate -20 to -5 & $17 \%$ & $5 \%$ & & $0.0 \%$ \\
\hline Overvaluation Over 100 percent & $5 \%$ & $14 \%$ & & $-0.2 \%$ \\
\hline Overvaluation 50 to 100 percent & $16 \%$ & $11 \%$ & & $0.0 \%$ \\
\hline $\begin{array}{l}\text { Residual Trade Share }-40 \text { Below } \\
\text { Predicted }\end{array}$ & $8 \%$ & $3 \%$ & & $-0.1 \%$ \\
\hline $\begin{array}{l}\text { Residual Trade Share }-40 \text { to }-30 \\
\text { Below Predicted }\end{array}$ & $14 \%$ & $8 \%$ & & $-0.1 \%$ \\
\hline
\end{tabular}

Table 7b: Changes in policy outcomes from 1980-88 to 1989-1998 for Latin America and predicted growth changes (Coefficients for predicted growth from core regression in column 1 of Table 6 controlling for all policies and country and year effects)

A similar story holds for Latin America in Table 7b. There was a sizeable increase in growth from 1980-88 to 1989-98 in Latin America, but reform outcomes do not help to explain it. Substantial change in the prevalence of an extreme black market premium had a weak estimated effect. Extreme inflation shows some decrease in prevalence, but not as much as would happen later, as earlier shown in Table 5b. The other three policies show not much improvement in outcomes, combined with low or reversed growth effects from Table 6. 
The results with Africa and Latin America with the old dataset before 1998 are consistent with the old conventional wisdom in the literature that reform outcomes were disappointing. This was partly because the data failed to confirm much growth payoff associated with reforms, and partly because the data did not show as much reform as would become apparent with the addition of data from 1999-2015. The new data showed a disappearance of most extreme policy outcomes in the new millennium, and the new data then gave a long post-reform period that was not available in the pre-1998 data.

\section{Conclusion}

The introduction noted the frequent citation of stylized facts in the earlier literature that doubted the growth payoff to reforms that were included in the Washington Consensus (also known as globalizing or neoliberal reforms).

This point is so important that it warrants some repetition of quotes from the literature in the introduction (including from this author): "The ... Washington Consensus \{has\} not produced the desired results” (Rodrik 2006). "Repeated \{structural\} adjustment lending ...fails to show any positive effect on ... growth (Easterly 2005).” “The Lost Decades” for Latin America and Africa constituted disappointing "Stagnation in Spite of Policy Reform 1980-1998” (Easterly 2001). Rodrik (2006) noted "growth has been below expectations in Latin America" and "success stories in Sub-Saharan Africa are \} few and far in between." The Barcelona Development Agenda (2004) noted "The mediocre record of reforms in igniting sustained economic growth.” Krugman (1995) noted "the real economic performance of countries that had recently adopted Washington consensus policies...was distinctly disappointing.” (Burki and Edwards, 1995) said "after all the reforms.... \{Latin America\} is making little progress towards breaking out of the quagmire of poverty".

So the previous stylized facts on reforms and poor growth outcomes led to an almost universal verdict that advocacy for liberalizing reforms was "dead."

This paper produces new stylized facts of further changes in reform outcomes that have happened since the sample period of the earlier literature. Both extremely bad and moderately bad policy outcomes were surprisingly common in the 1980s and early 1990s, while such outcomes have mostly disappeared since then. 
This policy revolution has received little attention in the previous literature. Documenting it is one of the main contributions of this paper. Explaining how this happened would be a fascinating topic for future research. There are many possible explanations - did the Washington Consensus advice have a delayed positive effect on reform after all? Did the human capital of policymakers increase over time, so as to change destructive policies? The common trends could be consistent with an exogenous international trend towards reform, although this cannot be resolved definitively.

The results are also an interesting case study in the use of evidence in the political economy of reform. When new reforms are announced with as much fanfare as the Washington Consensus, there is pressure to evaluate the reforms as soon as possible. This can lead to what this paper documents, to premature pessimism about reform before the reform process is even complete and before enough postreform growth is available. Later results may show this pessimism to be mistaken, but there is much less interest in evaluating reforms by that point. This may help explain why it is so difficult to do reforms and why corrections to extremely bad policy outcomes are delayed. Exploring such political economy outcomes further would also be a fruitful topic for further research.

This paper showed these changes in policy outcomes - especially away from extreme policies -- were accompanied by growth increases. It documented that the policy reforms can explain the growth increases in the regions most emphasized earlier - Africa and Latin America. We have seen that the old data available through 1998 was indeed consistent with the reform pessimism, partly because of weaker results on growth payoffs associated with reform outcomes and partly because less reform had happened.

None of these statements resolve causality. But if the earlier stylized facts induced doubts about the value of reform, the new stylized facts should cause some updating of beliefs towards a more positive view of these policy reforms.

The new stylized facts also are suggestive that the literature (including this author) may have gone too far on proclaiming complete ignorance on policies and growth: "Perhaps we will never learn where \{growth \} will start or what will make it continue.” (Banerjee 2009), "the economics profession does not have this 
knowledge \{how to raise growth\}" (Easterly 2009) and "We Learn Nothing from Regressing Economic Growth on Policies” (Rodrik 2012). The evidence here supports mainstream theoretical predictions that extreme policies kill off growth, while reversal of extreme policies will allow growth recoveries.

The new stylized facts seem most consistent with a position in between the poles of complete dismissal or vindication of the Washington Consensus. Even if the new stylized facts were interpreted as causal, they would still hardly constitute a blanket triumph of the Washington Consensus. As already noted, major reform areas like fiscal adjustment, privatization, and deregulation are omitted due to lack of good indicators.

And the most robust results are only about the most extreme policy ranges. Even critics of the Washington Consensus might agree that extreme ranges of inflation, black market premiums, overvaluation, negative real interest rates, and repression of trade were undesirable. The finding that moderately bad policies are not very robust predictors of growth could even possibly support a criticism of the Washington Consensus that it was too obsessive about getting policies exactly right. $^{18}$

Despite these caveats, the new stylized facts are consistent with a more positive view of reform, compared to the previous consensus on doubting reform. The reform critics (including this author) failed to emphasize the dangers of extreme policies in the previous reform literature, or to note how common were the extreme policies. Even if the reform movement was far from a complete shift to "free market policies," it at least seems to have accomplished the elimination of the most extreme policy distortions of markets, which is associated with the revival of growth in Africa, Latin America, and in other countries that had extreme policies.

\footnotetext{
${ }^{18}$ However, note again the repeated cautions in this paper against interpreting insignificant effects as zero effects.
} 


\section{Bibliography}

Banerjee, Abhijit. 2009. "Big Answers for Big Questions: The Presumption of Growth Policy.” In Jessica Cohen and William Easterly, editors. What Works in Development?: Thinking Big and Thinking Small. Brookings Institution Press. Washington DC

Bazzi Samuel and Christopher Blattman, Economic Shocks and Conflict: Evidence from Commodity Prices, American Economic Journal: Macroeconomics 2014, 6(4): 1-38

Beck, T., Levine, R. \& Loayza, N., 2000. Finance and the sources of growth. Journal of Financial Economics, 58(1-2), pp.261-300.

Bekaert, G., Harvey, C.R. \& Lundblad, C., 2005. Does financial liberalization spur growth? Journal of Financial Economics, 77(1), pp.3-55.

Billmeier, A. \& Nannicini, T., 2013. Assessing Economic Liberalization Episodes: a Synthetic Control Approach. The Review of Economics and Statistics, 95(3), pp.983-1001.

Bruno, Michael and William Easterly. "Inflation Crises and Long-run Growth", Journal of Monetary Economics 41 February 1998, 3-26.

Burki, S.J., Edwards, S., 1995. "Latin America After Mexico: Quickening the Pace”. Office of the Vice President, Latin America and the Caribbean Region, the World Bank, June.

Dollar, D. \& Kraay, A., 2004. Trade, Growth, and Poverty. The Economic Journal, 114(493), pp.F22-F49.

Durlauf, S., P. Johnson and J. Temple, "Growth Econometrics," in Handbook of Economic Growth, P. Aghion and S. Durlauf, eds., Amsterdam: North Holland, 2006. 
Easterly, W., M. Kremer, L. Pritchett, and L. Summers) "Good Policy or Good Luck? Country Growth Performance and Temporary Shocks," Journal of Monetary Economics, Vol. 32, December 1993, 459-483.

Easterly, William and Ross Levine. Tropics, Germs, and Crops: The Role of Endowments in Economic Development, Journal of Monetary Economics, Vol. 50, Issue 1, 3-39. January 2003

Easterly, William. "What did structural adjustment adjust? The association of policies and growth with repeated IMF and World Bank adjustment loans," Journal of Development Economics 76 (1), (February 2005a), 1-22.

. "National policies and economic growth: a reappraisal," in Philippe Aghion and Steven Durlauf, Handbook of Economic Growth, North Holland, 2005b

. "The Lost Decades: Explaining Developing Countries' Stagnation in spite of policy reform 1980- 1998” Journal of Economic Growth, Volume 6, Issue 2, June 2001, 135-157

Edwards, Sebastian, “'Openness, Productivity and Growth: What Do We Really Know?’' Economic Journal 108:447 (1998), 383-398.

Edwards, S., 1995. Crisis and Reform in Latin America: From Despair to Hope. The World Bank, Oxford University Press.

Estevadeordal, Antoni and Alan M. Taylor. IS THE WASHINGTON CONSENSUS DEAD? GROWTH, OPENNESS, AND THE GREAT LIBERALIZATION, 1970S-2000S, The Review of Economics and Statistics, December 2013, 95(5): 1669-1690

Fischer, S. Comment on Jeffrey D. Sachs, and Andrew Warner. 1995. "Economic Reform and the Process of Global Integration." Brookings Papers on Economic Activity 1:1-118. 
Frankel, J. \& Romer, D., 1999. Does Trade Cause Growth? American Economic Review, 89(3), pp.379-399

Gramacy, Robert B., Samuel W. Malone, and Enrique ter Horst, "Exchange Rate Fundamentals, Forecasting, and Speculation: Bayesian Models in Black Markets", Journal of Applied Econometrics, Vol. 29, No. 1, 2014, pp. 22-41.

Harrison, Ann, 'Openness and Growth: A Time-Series, Cross-Country Analysis for Developing Countries,'” Journal of Development Economics 48 (1996), 419-447.

Irwin, Douglas. Clashing Over Commerce: A History of US Trade Policy. University of Chicago Press. 2017 (forthcoming)

Jones, Charles I. "The Facts of Economic Growth" Handbook of Macroeconomics, 2016.

King, Robert G. and Levine, Ross. "Finance and Growth: Schumpeter Might Be Right," Quarterly Journal of Economics, August 1993, 108(3), pp. 717-38.

Krugman, P., 1995. "Dutch Tulips and Emerging Markets.” Foreign Affairs, July/August 1995, Volume 74, Number 4 pp. 28-44.

Laeven, Luc, Ross Levine, and Stelios Michalopoulos . 2015, "Financial Innovation and Endogenous Growth." Journal of Financial Intermediation, January, 24(1):1-24

Levine, Ross. "Finance and Growth: Theory and Evidence." in Handbook of Economic Growth, Eds:Philippe Aghion and Steven Durlauf, The Netherlands: Elsevier Science, 2005.

Levine, R., 1997. Financial development and economic growth: views and agenda. Journal of Economic Literature, XXXV(June), pp.688-726. 
Levine, R and D Renelt. 1992. "A sensitivity analysis of cross-country growth regressions.” The American Economic Review.

Marrazzo, Pasquale Marco and Alessio Terzi, Wide-reaching structural reforms and growth: a cross-country synthetic control approach, mimeo, 28 APRIL 2017

McKinnon, Ronald. 1973. Money and Capital in Economic Development. Brookings.

Naidu, Suresh, Dani Rodrik, and Gabriel Zucman. "Economics After Neoliberalism.” Boston Review, Summer 2019.

Pritchett, Lant, Kunal Sen, and Eric Werker. 2017. "Deals and Development - An Introduction to the Conceptual Framework, in Lant Pritchett, Kunal Sen, and Eric Werker, editors, Deals and Development: The Political Dynamics of Growth Episodes, Oxford University Press.

Rajan, R.G. \& Zingales, L., 1998. Financial Dependence and Growth. American Economic Review, 88(3), pp.559-586.

Rodrik, Dani. "Understanding Economic Policy Reform," Journal of Economic Literature, March 1996.

. Has Globalization Gone Too Far?, Institute for International Economics, Washington, DC, 1997

. Comments on "Trade, Growth, and Poverty," by D. Dollar and A. Kraay, Harvard University, October 2000

. “Goodbye Washington Consensus, Hello Washington Confusion?” Journal of Economic Literature, XLIV, December 2006, 969-983.

. One Economics, Many Recipes: Globalization, Institutions, and Economic Growth. Princeton University Press: Princeton NJ. 2008. 
. “Do We Need to Rethink Growth Policies?” in Olivier J. Blanchard, David Romer, Michael Spence, and Joseph E. Stiglitz, eds., In the Wake of the Crisis: Leading Economists Reassess Economic Policy, MIT Press, Cambridge and London, 2012.

. Why We Learn Nothing from Regressing Economic Growth on Policies. Seoul Journal of Economics. 2012.

Rodriguez, Francisco, and Dani Rodrik. 2000. "Trade Policy and Economic Growth: A Skeptic’s Guide to the Cross-National Evidence.” In Ben Bernanke, and Kenneth Rogoff, eds., NBER Macroeconomics Annual 2000. Cambridge, Mass.: MIT Press.

Sachs, Jeffrey D., and Andrew Warner. 1995. "Economic Reform and the Process of Global Integration. "Brookings Papers on Economic Activity 1:1- 118.

Stiglitz, Joseph. "Nobel Prize-winning economist Stiglitz tells us why 'neoliberalism is dead,'” Business Insider, Aug. 19, 2016. http://www.businessinsider.com/joseph-stiglitz-says-neoliberalism-is-dead-2016-8

Wacziarg, R. \& Welch, K.H., 2008. Trade liberalization and growth: New evidence. World Bank Economic Review, 22(2), pp.187-231

Williamson, John. 1990 "What Washington Means by Policy Reform," Chapter 2 in Latin American Adjustment: How Much Has Happened? (Washington: Institute for International Economics.)

World Bank. 2005. Economic Growth in the 1990s: Learning from a Decade of Reform, Washington DC. 


\section{Appendix}

\section{Data Description and Issues}

Per capita GDP Growth

WDI series NY.GDP.PCAP.KD.ZG, converted from percent growth per annum to logarithmic growth per annum.

\section{Inflation}

WDI series FP.CPI.TOTL.ZG

\section{Black market premium}

For obvious reasons, black market outcomes are not typically reported by official sources and are not easy to observe, so this series will be spottier and perhaps have a larger margin of error than the others. This paper updates black market premium data previously collected by the Global Development Network Growth Database (2001).$^{19}$ One source for the updates is the website "Global Financial Data", which reports a black market rate corresponding to "the operational rates of exchange used by the United Nations for personnel in those countries." 20 Another source is Gramcy et al. (2014). The corresponding official exchange rate (annual average) is from the IMF International Financial Statistics. We also need to include the zeroes for countries that do not have a black market in foreign exchange. These countries are identified by year from the the IMF's "Annual Report on Exchange Arrangements and Exchange Restrictions" - zeroes are imputed where there are no restrictions on foreign exchange. Gaps in these sources mean that no data is available for 1994-95 and 2000-2005.

\footnotetext{
${ }^{19}$ This author and Mirvat Sewadeh collected the data for this database. The sources given in the 2001 database for the black market exchange rate were Levine and Renelt 1992; World Currency Yearbook (1985, 1990-93); Adrian Wood 1988 "Global trends in real exchange rates: 1960-84" (filling in missing observations); Global Development Finance \& World Development Indicators (1996-1997, formula: (parallel Xrate/official Xrate-1)*100 ); values for industrial countries were added as 0 .

${ }^{20}$ The website is here.
} 


\section{Real interest rate}

The Deposit interest rate is "the rate paid by commercial or similar banks for demand, time, or savings deposits." ${ }^{21}$

\section{Real overvaluation}

The starting place is the "Purchasing power parity conversion factor" for 2005, which is "the number of units of a country's currency required to buy the same amounts of goods and services in the domestic market as U.S. dollar would buy in the United States." 22 This number was produced by the International Comparisons Project (ICP) for the 2005 benchmark. This is then divided by the country's actual official exchange rate of local currency per dollar for 2005.

This ratio is greater than one when the prices of goods in dollars in the local economy (converted at the official exchange rate) is greater than the prices of the same goods in dollars in the U.S., implying the domestic currency is overvalued.

Another factor in overvaluation outcomes, as has long been known, is the relative poverty of the country. Nontraded goods tend to be cheaper in dollars the poorer is the country, making it appear according to the above calculation that most poor countries have undervalued currencies. Hence, the raw overvaluation index is regressed here on the log per capita GDP in PPP terms for 2005 and a predicted overvaluation is constructed based on that regression. ${ }^{23}$ The adjusted overvaluation index for 2005 will be the raw index divided by the predicted index. The index is then 100 in 2005 when there is no adjusted overvaluation, while an index of 150 would suggest 50 percent adjusted overvaluation.

\footnotetext{
${ }^{21}$ (FR.INR.DPST according to WDI)

22 (WDI series PA.NUS.PPP.05)

${ }^{23}$ The regression excludes the oil-dependent economies Bahrain, Brunei, Equatorial Guinea, Kuwait, Libya, Oman, Qatar, Russia, Saudi Arabia, Trinidad, and UAE, as exchange rate policy as a different meaning in such economies. It also excludes extreme outliers in the raw overvaluation measured in 2005. Ecuador, El Salvador, Estonia, Liberia, Slovak Republic, and Slovenia are more than 90 percent undervalued. Myanmar is an extreme outlier in the other direction, overvalued by a factor of 43 . These outliers can result from using the wrong exchange rate when there are multiple exchange rates, or other errors.
} 
The benchmark overvaluation index is extended to other years using the percent changes in the real exchange rate index, which is defined as (Nominal official exchange rate)*(US CPI index)/(Domestic CPI index).

\section{Trade to GDP Ratio}

The Trade Ratio is also affected by other non-policy characteristics of the economy, the most obvious one being that smaller countries tend to have higher trade ratios than larger economies. The step to correct for this is to regress the trade ratio on the log of population size, and then compare the actual Trade Ratio to the predicted one.

\section{The Role of Sample Size in the Regressions}

In regressions that control for all policy effects at once, or also include wars and commodity shocks, there are two things that affect the significance of any one coefficient - the controls for other variables, and the reduction in sample size compared to regressions with less controls. This appendix explores the role of the latter by rerunning the regressions in Table 3 and 4 on smaller sample sizes. Appendix Table 1 will rerun regressions on columns (2) through (6) of Table 3 for the restricted sample of column (1) of Table 2. Appendix Table 2 will rerun all regressions in Table 4 without controlling for wars and commodity shocks, but restricting the sample to those observations in which data for wars and commodity shocks were available. 
Regression of growth on policy outcomes, controlling for country and year effects, restricted to column (1) sample for all policy variables

\begin{tabular}{|l|l|l|l|l|}
\hline $\begin{array}{l}\text { Dummy for Black Market Premium } 20 \text { to } \\
40\end{array}$ & & & & \\
\hline
\end{tabular}

Appendix Table 1: Rerunning Table 3 regressions restricting sample to be the same in columns (2) through (6) as for column (1)

Appendix Table 1 shows the insignificance of some moderately bad policy variables in the full regression in column (1) of Table 2 happens also in the "one policy at a time" regressions in columns (2) through (6) when restricted to the column (1) sample for the full regression. 
Regressions of growth on policy outcomes for sample of wars and commodity price shocks

\begin{tabular}{|c|c|c|c|c|c|c|}
\hline & (1) & (2) & (3) & (4) & (5) & (6) \\
\hline $\begin{array}{l}\text { Dummy for Black Market Premium } 20 \text { to } \\
40\end{array}$ & -0.00399 & -0.00505 & & & & \\
\hline & $(0.00485)$ & $(0.00426)$ & & & & \\
\hline $\begin{array}{l}\text { Dummy for Black Market Premium Over } \\
40\end{array}$ & $-0.0116^{* *}$ & $-0.0197 * * *$ & & & & \\
\hline & $(0.00529)$ & $(0.00373)$ & & & & \\
\hline Dummy for Inflation 20 to 40 & $-0.00929 *$ & & $0.00984 * * *$ & & & \\
\hline & $(0.00493)$ & & $(0.00340)$ & & & \\
\hline Dummy for Inflation Over 40 & $-0.0291 * * *$ & & $-0.0351 * * *$ & & & \\
\hline & $(0.00708)$ & & $(0.00409)$ & & & \\
\hline Dummy for Real Interest Rate -20 to -5 & -0.000837 & & & $-0.00545^{*}$ & & \\
\hline & $(0.00407)$ & & & $(0.00299)$ & & \\
\hline Dummy for Real Interest Rate Below -20 & 0.00159 & & & $-0.0234 * * *$ & & \\
\hline & $(0.00913)$ & & & $(0.00487)$ & & \\
\hline $\begin{array}{l}\text { Dummy for Overvaluation } 50 \text { to } 100 \\
\text { percent }\end{array}$ & -0.00187 & & & & $-0.00728 * *$ & \\
\hline & $(0.00444)$ & & & & $(0.00311)$ & \\
\hline $\begin{array}{l}\text { Dummy for Overvaluation Over } 100 \\
\text { percent }\end{array}$ & $-0.0115^{*}$ & & & & $-0.0213^{* * *}$ & \\
\hline & $(0.00602)$ & & & & $(0.00411)$ & \\
\hline $\begin{array}{l}\text { Dummy for Residual Trade Share }-40 \text { to - } \\
30 \text { Below Predicted }\end{array}$ & $-0.0107 * *$ & & & & & $-0.00796 * *$ \\
\hline & $(0.00529)$ & & & & & $(0.00332)$ \\
\hline $\begin{array}{l}\text { Dummy for Residual Trade Share - } 40 \\
\text { Below Predicted }\end{array}$ & $-0.0225 * * *$ & & & & & $-0.0109 * * *$ \\
\hline & $(0.00637)$ & & & & & $(0.00386)$ \\
\hline Observations & 1,341 & 3,117 & 3,611 & 2,431 & 3,061 & 4,184 \\
\hline R-squared & 0.143 & 0.059 & 0.080 & 0.086 & 0.075 & 0.055 \\
\hline Number of countrynumber & 88 & 114 & 110 & 104 & 97 & 115 \\
\hline
\end{tabular}

Standard errors in parentheses $* * * \mathrm{p}<0.01, * * \mathrm{p}<0.05, * \mathrm{p}<0.1$

Appendix Table 2: Re-running Table 4 regressions for the same sample as in each column of Table 3, but not controlling for wars or commodity shocks

Appendix Table 2 also shows that some of the non-significance of moderate policies in the regressions controlling for wars and commodity shocks in table 4 may have been partly due to sample restriction. This table shows the same nonsignificance of moderate policies for the smaller samples, even when not controlling for wars and commodity shocks. 


\section{Robustness checks for alternative thresholds for moderately and extremely bad policies}

This section tests the robustness of the results to alternative thresholds to define moderately bad and extremely bad policies. We will first adjust the thresholds all upward in absolute value and then adjust them all downward. The first makes the definition of extreme policies more extreme, and the second makes the definitions less extreme.

So for example, for the upward adjustment we will define extremely bad inflation as greater than 50 percent (compared to baseline of 40 percent), and moderately bad inflation as between 30 and 50 percent (compared to baseline of 20 to 40 percent). For extreme policies defined in the negative direction, we will make the threshold more negative - so extremely bad real interest rates will now be defined as less than -30 percent instead of the baseline of less than -20 percent .

Appendix Table 3 shows the results. Entering each policy one at a time as before in columns (2) through (6), all policy dummies are still significant. Entering all policy dummies at once in column (1), three of the extreme policy dummies are significant, while the extreme real interest rate dummy is marginally significant at the 10 percent level. Two moderately bad policy dummies are also significant, while two others are marginally significant at the 10 percent level. 
Regressions of per capita growth on policy dummies, adjusting upward in absolute value the policy thresholds, controlling for country and year fixed effects

\begin{tabular}{|c|c|c|c|c|c|c|}
\hline & (1) & (2) & (3) & (4) & (5) & (6) \\
\hline $\begin{array}{l}\text { Dummy for black market premium between } 30 \text { and } \\
50 \text { percent }\end{array}$ & $-0.00926^{*}$ & $-0.0175^{* * *}$ & & & & \\
\hline & $(0.00544)$ & $(0.00393)$ & & & & \\
\hline $\begin{array}{l}\text { Dummy for black market premium above } 50 \\
\text { percent }\end{array}$ & -0.00686 & $-0.0218 * * *$ & & & & \\
\hline & $(0.00462)$ & $(0.00304)$ & & & & \\
\hline Dummy for inflation between 30 and 50 percent & $-0.0105^{*}$ & & $-0.0213^{* * *}$ & & & \\
\hline & $(0.00570)$ & & $(0.00380)$ & & & \\
\hline Dummy for inflation above 50 percent & $-0.0262 * * *$ & & $-0.0412^{* * *}$ & & & \\
\hline & $(0.00604)$ & & $(0.00347)$ & & & \\
\hline $\begin{array}{l}\text { Dummy for Real interest rate between - } 15 \text { and - } 30 \\
\text { percent }\end{array}$ & 0.00207 & & & $-0.0138 * * *$ & & \\
\hline & $(0.00658)$ & & & $(0.00461)$ & & \\
\hline Dummy for Real interest rate below - 30 percent & $-0.0163^{*}$ & & & $-0.0457 * * *$ & & \\
\hline & $(0.00910)$ & & & $(0.00566)$ & & \\
\hline $\begin{array}{l}\text { Dummy for overvaluation between } 75 \text { and } 125 \\
\text { percent }\end{array}$ & $-0.0154 * * *$ & & & & $-0.00985^{* * *}$ & \\
\hline & $(0.00393)$ & & & & $(0.00286)$ & \\
\hline Dummy for Overvaluation more than 125 percent & $-0.0161^{* * *}$ & & & & $-0.0193^{* * *}$ & \\
\hline & $(0.00611)$ & & & & $(0.00384)$ & \\
\hline $\begin{array}{l}\text { Dummy for trade share } 40 \text { to } 50 \text { percent below } \\
\text { predicted }\end{array}$ & $-0.0158 * * *$ & & & & & $-0.0101 * * *$ \\
\hline & $(0.00447)$ & & & & & $(0.00308)$ \\
\hline $\begin{array}{l}\text { Dummy for trade share more than } 50 \text { percent below } \\
\text { predicted }\end{array}$ & $-0.0181 * * *$ & & & & & $-0.0166^{* * *}$ \\
\hline & $(0.00695)$ & & & & & $(0.00421)$ \\
\hline Observations & 2,442 & 5,403 & 6,760 & 4,806 & 5,250 & 7,695 \\
\hline R-squared & 0.156 & 0.075 & 0.085 & 0.085 & 0.079 & 0.061 \\
\hline Number of countrynumber & 129 & 189 & 178 & 170 & 146 & 192 \\
\hline
\end{tabular}

Appendix Table 3: Regression of per capita growth on policy dummies controlling for country and year fixed effects, adjusting upward in absolute values thresholds for defining moderately bad and extremely bad policies

We next do a downward adjustment of thresholds for extreme policies. Extremely bad inflation is now defined as greater than 30 percent (instead of 40 in the baseline), while moderately bad inflation is defined as 10 to 30 percent (instead of 20 to 40 in the baseline). Extremely bad real interest rates are defined as less than 10 percent (compared to -20 percent in the baseline), while moderately bad is defined as between 0 and -10 percent (instead of -5 to -20 percent in the baseline). ${ }^{24}$

\footnotetext{
${ }^{24}$ We do not adjust the lower end of moderately bad real interest rates from -5 all the way to +5 because positive real interest rates do not suggest a policy distortion.
} 
Appendix Table 4 shows the results with downward adjustment of all policy thresholds in absolute value. Entering policies one at a time in columns (2) through (6), all the dummies for extreme policies are still significant.

Regressions of per capita growth on policy dummies, adjusting downward in absolute value the policy thresholds, controlling for country and year fixed effects

\begin{tabular}{|c|c|c|c|c|c|c|}
\hline & (1) & $(2)$ & (3) & (4) & (5) & (6) \\
\hline \multirow[t]{2}{*}{$\begin{array}{l}\text { Dummy for black market premium } \\
\text { between } 10 \text { and } 30 \text { percent }\end{array}$} & -0.00299 & -0.00387 & & & & \\
\hline & $(0.00311)$ & $(0.00273)$ & & & & \\
\hline \multirow[t]{2}{*}{$\begin{array}{l}\text { Dummy for black market premium above } \\
30 \text { percent }\end{array}$} & $-0.00962 * *$ & $-0.0220 * * *$ & & & & \\
\hline & $(0.00409)$ & $(0.00288)$ & & & & \\
\hline \multirow[t]{2}{*}{ Dummy for inflation between 10 and 30} & -0.00206 & & $-0.00343^{*}$ & & & \\
\hline & $(0.00262)$ & & $(0.00187)$ & & & \\
\hline \multirow[t]{2}{*}{ Dummy for inflation above 30 percent } & $-0.0197 * * *$ & & $-0.0342 * * *$ & & & \\
\hline & $(0.00483)$ & & $(0.00294)$ & & & \\
\hline \multirow[t]{2}{*}{$\begin{array}{l}\text { Dummy for Real interest rate between } 0 \\
\text { and }-10 \text { percent }\end{array}$} & 0.00317 & & & 0.000585 & & \\
\hline & $(0.00211)$ & & & $(0.00172)$ & & \\
\hline \multirow[t]{2}{*}{ Dummy for Real interest rate below -10 } & $-0.00811^{*}$ & & & $-0.0214^{* * *}$ & & \\
\hline & $(0.00475)$ & & & $(0.00320)$ & & \\
\hline \multirow[t]{2}{*}{$\begin{array}{l}\text { Dummy for overvaluation between } 25 \text { and } \\
75 \text { percent }\end{array}$} & $-0.00584^{* *}$ & & & & $-0.00884 * * *$ & \\
\hline & $(0.00242)$ & & & & $(0.00187)$ & \\
\hline \multirow[t]{2}{*}{$\begin{array}{l}\text { Dummy for Overvaluation more than } 75 \\
\text { percent }\end{array}$} & $-0.0200 * * *$ & & & & $-0.0181 * * *$ & \\
\hline & $(0.00413)$ & & & & $(0.00279)$ & \\
\hline \multirow[t]{2}{*}{$\begin{array}{l}\text { Dummy for trade share } 20 \text { to } 30 \text { percent } \\
\text { below predicted }\end{array}$} & -0.00430 & & & & & -0.00377 \\
\hline & $(0.00308)$ & & & & & $(0.00246)$ \\
\hline \multirow[t]{5}{*}{$\begin{array}{l}\text { Dummy for trade share more than } 30 \\
\text { percent below predicted }\end{array}$} & $-0.0166 * * *$ & & & & & $-0.0118 * * *$ \\
\hline & $(0.00389)$ & & & & & $(0.00263)$ \\
\hline & 2,442 & 5,403 & 6,760 & 4,806 & 5,250 & 7,695 \\
\hline & 0.158 & 0.076 & 0.083 & 0.081 & 0.082 & 0.061 \\
\hline & 129 & 189 & 178 & 170 & 146 & 192 \\
\hline
\end{tabular}

Standard errors in parentheses, ${ }^{* * *} \mathrm{p}<0.01,{ }^{* *} \mathrm{p}<0.05,{ }^{*} \mathrm{p}<0.1$

Appendix Table 4: Regression of per capita growth on policy dummies controlling for country and year fixed effects, adjusting downward in absolute values thresholds for defining moderately bad and extremely bad policies

However, only one of the dummies for moderately bad policies is significant (with another one at 10 percent significance). This contrasts with the significance of all these dummies in the baseline regressions in Table 3 and in the upward adjustment of thresholds in Appendix Table 4. 
Entering all policy dummies at the same time in Column 1 of Appendix Table 4, 4 of the 5 extreme policy dummies are significant, while the extreme real interest rate dummy is significant at the 10 percent level. Only one of the five moderately bad policy dummies is significant in Column 1.

The results for extreme policy dummies are mostly robust to upward or downward adjustments of thresholds to define the extreme range. However, Appendix Table 4 overall -- compared to Table 3 and Appendix Table 3 -- shows a weakening of results on moderately bad policies when they are redefined downward to be even more moderate. This is consistent with previous results from the literature (as cited above) that the growth associations with moderately bad policies have been hard to detect. 